\title{
Comparative genomics and proteomics of Helicobacter mustelae, an ulcerogenic and carcinogenic gastric pathogen
}

\author{
Paul W O'Toole ${ }^{1 *}$, William J Snelling ${ }^{2}$, Carlos Canchaya ${ }^{3}$, Brian M Forde ${ }^{1}$, Kim R Hardie ${ }^{4}$, Christine Josenhans ${ }^{5}$, \\ Robert LJ Graham², Geoff McMullan², Julian Parkhill', Eugenio Belda ${ }^{6,7}$, Stephen D Bentley ${ }^{6}$
}

\begin{abstract}
Background: Helicobacter mustelae causes gastritis, ulcers and gastric cancer in ferrets and other mustelids. $\mathrm{H}$. mustelae remains the only helicobacter other than $\mathrm{H}$. pylori that causes gastric ulceration and cancer in its natural host. To improve understanding of $\mathrm{H}$. mustelae pathogenesis, and the ulcerogenic and carcinogenic potential of helicobacters in general, we sequenced the H. mustelae genome, and identified 425 expressed proteins in the envelope and cytosolic proteome.

Results: The H. mustelae genome lacks orthologs of major $\mathrm{H}$. pylori virulence factors including CagA, VacA, BabA, SabA and OipA. However, it encodes ten autotransporter surface proteins, seven of which were detected in the expressed proteome, and which, except for the Hsr protein, are of unknown function. There are 26 putative outer membrane proteins in $\mathrm{H}$. mustelae, some of which are most similar to the Hof proteins of $\mathrm{H}$. pylori. Although homologs of putative virulence determinants of H. pylori (NapA, plasminogen adhesin, collagenase) and Campylobacter jejuni (CiaB, Peb4a) are present in the H. mustelae genome, it also includes a distinct complement of virulence-related genes including a haemagglutinin/haemolysin protein, and a glycosyl transferase for producing blood group A/B on its lipopolysaccharide. The most highly expressed 264 proteins in the cytosolic proteome included many corresponding proteins from $\mathrm{H}$. pylori, but the rank profile in $\mathrm{H}$. mustelae was distinctive. Of 27 genes shown to be essential for $\mathrm{H}$. pylori colonization of the gerbil, all but three had orthologs in $\mathrm{H}$. mustelae, identifying a shared set of core proteins for gastric persistence.

Conclusions: The determination of the genome sequence and expressed proteome of the ulcerogenic species $\mathrm{H}$ mustelae provides a comparative model for $\mathrm{H}$. pylori to investigate bacterial gastric carcinogenesis in mammals, and to suggest ways whereby cag minus $H$. pylori strains might cause ulceration and cancer.

The genome sequence was deposited in EMBL/GenBank/DDBJ under accession number FN555004.
\end{abstract}

\section{Background}

The genus Helicobacter contains over 50 species, and a large number of candidate or unclassified species, which have been isolated from a wide range of vertebrate hosts (reviewed by Solnick and Vandamme [1]). The type species is Helicobacter pylori (reviewed in ref. [2]), which is a causative agent for duodenal ulcers \& peptic ulcers $[3,4]$, is a risk factor for gastric adenocarcinoma [5] and for B cell MALT lymphoma [6]. The majority of

\footnotetext{
* Correspondence: pwotoole@ucc.ie
'Department of Microbiology, \& Alimentary Pharmabiotic Centre, University

* Correspondence: pwotoole@ucc.ie
'Department of Microbiology, \& Alimentary Pharmabiotic Centre, University College Cork, Cork, Ireland
}

(c) 2010 O'Toole et al; licensee BioMed Central Ltd. This is an Open Access article distributed under the terms of the Creative Commons Attribution License (http://creativecommons.org/licenses/by/2.0), which permits unrestricted use, distribution, and reproduction in any medium, provided the original work is properly cited.

Helicobacter species are not found in the stomach [7]. One enterohepatic species, $H$. hepaticus has been shown to cause chronic active hepatitis and typhocolitis in infected mice [8], development of liver carcinomas in infected mice [9], and induction of inflammatory bowel disease symptoms in mice [10]. This contrasts with the cases of other extragastric Helicobacter species, for example, with the association of "H. rappini" (taxonomic name not validly published) with disease in humans and companion animals (reviewed in ref. [7]). All of the gastric Helicobacter species produce a potent urease, as an acid protection mechanism, whereas the large number 
of enteric species (gastrointestinal, intestinal, hepatic and biliary) are not uniformly urease positive [7].

The ferret (Mustela putorius) is a valuable element in comparative medicine, providing inter alia models for human influenza [11] and infectious gastritis [12,13]. $H$. mustelae is a gastric pathogen of ferrets, and was the second member of the genus identified [14-16]. H. mustelae cells are smaller and typically less helical than those of $H$. pylori, with lateral as well as bipolar flagella [17]. H. mustelae is virtually endemic in ferrets $[12,18]$ and other mustelids [19], and like H. pylori, stimulates a humoral immune response [13], including in naturally infected animals [18], which does not clear the infection. Experimentally infected ferrets develop a gastritis which closely resembles the diffuse antral gastritis seen in some adults, and in children [20]. Ferret gastric epithelial cell proliferation increases upon $H$. mustelae infection [21], and the bacterium has been linked to gastric adenocarcinoma [22] and MALT lymphoma [23] in the infected ferret. Ulcer formation in $H$. mustelae-infected ferrets is also common; $H$. mustelae infection of ferrets is the only natural model of Helicobacter-associated ulcer disease, making it a unique model [13]. Although other recently discovered gastric Helicobacter species from marine mammals, pigs and companion animals may also cause gastric ulcers and cancer, the knowledge base and tractability of the ferret makes it an attractive animal model for human gastric disease due to Helicobacter infection [24].

Despite being isolated from the ferret stomach, phylogenetic analysis of $H$. mustelae based upon the $16 \mathrm{~S}$ rRNA gene positions it, with $H$. suncus, in a clade within the enteric helicobacters $[7,25]$. Interestingly, phylogenetic analysis based upon the 23S rRNA gene resulted in a discordant tree structure (from that based upon the 16S rRNA gene; [26]), in which $H$. mustelae was positioned even deeper among the enteric helicobacters. Another interesting outcome of that study was the positioning of another $\varepsilon$-proteobacterium, Wolinella succinogenes, between $H$. pylori and $H$. hepaticus, when orthology levels of 870 core proteins were analyzed [26]. $H$. mustelae was not included in that analysis because a genome sequence was not available.

Driven to a large extent by the desire to understand their pathogenesis at a molecular level, many of the $\varepsilon$ proteobacteria have been subjected to genomic analyses. In addition to two early $H$. pylori genome sequence determinations $[27,28]$, draft or complete genome sequences for 11 additional $H$. pylori strains are lodged with NCBI Genome Projects http://www.ncbi.nlm.nih. gov/Entrez/. However no whole genome sequence for gastric Helicobacter species other than H. pylori, and the closely related $H$. acinonychis, is available so far. Genome sequence projects of an additional five extragastric species ( $H$. pullorum, $H$. bilis, $H$. winghamensis, $H$, canadensis, and $H$. cinaedi) are currently underway at the Broad Institute http://www.broadinstitute.org/. The genomes of $H$. hepaticus [29], and $H$. acinonychis [30] have been sequenced, as have those of Campylobacter jejuni [31,32], C. lari, C. uppsaliensis and C. coli [33], and W. succinogenes [34]. Comparative genomic analysis of four of these Campylobacterales species - H. pylori, H. hepaticus, C. jejuni, W. succinogenes, has been informative for identifying core proteins and specific adaptations to pathogenicity or commensalism in the respective species [35].

Relatively few $H$. mustelae strains have been characterized in detail at the molecular level. The genome size of $H$. mustelae was estimated by pulsed-field gel electrophoresis to be in the range of $1.685-1.69 \mathrm{Mb}$ for 15 strains examined [36], and the genome was apparently conserved among the strains at this low discrimination level. A number of presumptive virulence factors were identified in $H$. mustelae. A potent urease UreAB is implicated in acid-tolerance and pathology [37-39]. Ferrets may be therapeutically immunized against $H$. mustelae by administration of $H$. pylori urease protein [40]. The $H$. mustelae type strain 12198 was recently shown to produce a second urease enzyme UreAB2 which acts independently of nickel and accessory proteins. It appears to be representative of an adaptation by Helicobacter species that colonize the stomachs of carnivores, in which dietary nickel is limiting [41].

$H$. mustelae produces a surface array composed of ring-shaped protein aggregates of the Hsr protein [42], and which is required for persistent infection by $H$. mustelae in the ferret model [43]. We have shown that this surface protein is antigenically variable [44], suggesting it is subject to antibody pressure. Antigenic variation of the Hsr protein is achieved by recombining cassettes encoding epitopes in the passenger region of this autotransporter protein into the expression site [44]. These cassettes were detected in a $15 \mathrm{~kb}$ Hsr locus (HSRL), only a third of which is occupied by the expressed $h s r$ gene [44], the rest being devoted to sequences encoding alternative antigens. Another major surface antigen is the flagellum, the major components of which have been well studied [45,46]. Type strains of $H$. mustelae have been shown to produce a monofucosyl A type 1 histo-blood group epitope in their LPS [47] and antigastric auto-antibodies are elicited by the type strain 12198 (ATCC 43772) [48]. The structure of lipid A of H. mustelae strain 43772 differs from that of the lipid A of $H$. pylori [49].

Despite a limited genome-wide mutagenesis approach [50], relatively little about the genomic basis for H. mustelae persistence and pathogenesis in the ferret is known, since this organism has not benefitted from the 
pathogenomics approach that was applied to other Helicobacter species [51]. We report here the genome sequence of $H$. mustelae type strain 12198 , which is the first whole genome of a non- $H$. pylori-H. acinonychis gastric Helicobacter species. In addition, we compare the expressed proteome of $H$. mustelae with that of H. pylori. These data clarify the species-specific and host-specific adaptations by these gastric helicobacters, consolidate the phylogenomics of the genus, and significantly enhance the value of the ferret model for investigating helicobacter-related gastric disease.

\section{Results and Discussion}

\section{General $H$. mustelae Genome Features}

The general features of the $H$. mustelae genome are summarized in Table 1, and compared to selected other genomes of members of the Campylobacterales. The $H$. mustelae genome comprises a single circular chromosome of 1,578,097 base-pairs, and like most strains of the $\varepsilon$-proteobacteria selected for sequencing thus far, is plasmid-free. The GC content of the $H$. mustelae genome is the second highest among the Campylobacterales analyzed herein, and is among the highest values reported for members of the genus [7]. All the Campylobacterales genomes sequenced to date have similarly high coding densities. H. mustelae has slightly higher mean predicted CDS length than many other related bacteria, aided by the fact that the $H$. mustelae genome encodes some of the largest proteins ever recorded in this bacterial group (see below). Laterally acquired DNA in bacteria can be identified by local anomalies in GC mol\% content, and is often associated with IS elements or tRNA genes [52]. In pathogenic bacteria in general, such islands are typically associated with significant augmentation in virulence capability [53], and the $H$. pylori cag pathogenicity island is a key determinant of increased potential to cause more severe pathology including gastric ulcers and cancer [54]. The cag pathogenicity island of $H$. pylori is not present in H. mustelae, nor in any of the other helicobacters or campylobacters, including $H$. acinonychis which diverged relatively recently (ca. 200,00 years) from $H$. pylori [30]. Although

Table 1 General features of the $\boldsymbol{H}$. mustelae genome, and those of selected Campylobacterales

\begin{tabular}{|c|c|c|c|c|c|c|c|}
\hline \multirow{2}{*}{$\begin{array}{l}\text { Species } \\
\text { Strain }\end{array}$} & \multirow{2}{*}{$\begin{array}{l}\begin{array}{l}\text { Helicobacter } \\
\text { mustelae }\end{array} \\
{\text { ATCC } 43772^{\dagger}}_{12198}\end{array}$} & \multicolumn{2}{|c|}{ Helicobacter pylori } & \multirow{2}{*}{$\begin{array}{l}\begin{array}{l}\text { Helicobacter } \\
\text { acinonychis }\end{array} \\
\text { Sheeba [30] }\end{array}$} & \multirow{2}{*}{$\begin{array}{l}\begin{array}{l}\text { Helicobacter } \\
\text { hepaticus }\end{array} \\
\text { ATCC } 51449 \text { [29] }\end{array}$} & \multirow{2}{*}{$\begin{array}{l}\begin{array}{l}\text { Campylobacter } \\
\text { jejuni }\end{array} \\
\text { NCTC } 11168 \\
{[31]}\end{array}$} & \multirow{2}{*}{$\begin{array}{l}\begin{array}{l}\text { Wolinella } \\
\text { succinogenes }\end{array} \\
\text { DSM } 1740[34]\end{array}$} \\
\hline & & $26695[28]$ & J99 [27] & & & & \\
\hline Host(s) & Ferrets & Human & Human & Large felines & Rodent & Human \& avian & Bovine \\
\hline $\begin{array}{l}\text { Genome } \\
\text { size (bp) }\end{array}$ & $1,578,097$ & $1,667,867$ & $1,643,831$ & $1,553,928$ & $1,799,146$ & $1,641,481$ & $2,110,355$ \\
\hline $\begin{array}{l}\text { GC } \\
\text { content } \\
(\%)\end{array}$ & 42.47 & 39.0 & 39.0 & 38.2 & 35.9 & 30.6 & 48.5 \\
\hline $\begin{array}{l}\text { Predicted } \\
\text { ORFs }\end{array}$ & $1,403^{+}$ & $1,590(1,552[143])$ & 1,495 & 1,611 & 1,875 & 1,654 & 2,046 \\
\hline $\begin{array}{l}\text { Coding } \\
\text { area (\%) }\end{array}$ & $91.9 \%$ & 91.0 & 90.8 & 89.7 & 93.0 & 94.3 & 93.0 \\
\hline $\begin{array}{l}\text { Av.gene } \\
\text { length } \\
\text { (bp) }\end{array}$ & 995 & 945 & 998 & 865 & 1,082 & 948 & 964 \\
\hline Plasmids & None & None* & None* & One & None & None§ & None \\
\hline $\begin{array}{l}\text { Phages } \\
\text { and } \\
\text { phage- } \\
\text { like } \\
\text { elements }\end{array}$ & 4 phage genes & None & None & $\begin{array}{l}41 \text { phage } \\
\text { genes in two } \\
\text { prophage }\end{array}$ & 3 phage genes & None & Prophage-tRNAmet \\
\hline $\begin{array}{l}\text { IS } \\
\text { elements }\end{array}$ & None & IS605, IS606 & IS605 (partial), IS606 & ISHa1675 & None & Cj0752 (partial) & $\begin{array}{l}\text { ISWsu1302, } \\
\text { ISWsu1203 }\end{array}$ \\
\hline $\begin{array}{l}\text { Genomic } \\
\text { islands }\end{array}$ & None & cag PAl & cag PAl & $\begin{array}{l}\text { HAcG1 } \\
\text { integron }\end{array}$ & $\mathrm{HHGl1}$ & None & WsuGl I and II \\
\hline $\begin{array}{l}\text { Regions } \\
\text { of } \\
\text { deviating } \\
\text { GC } \\
\text { content }\end{array}$ & $\begin{array}{l}\text { Autotransporter } \\
\text { genes, flagellin } \\
\text { modification, } \\
\text { surface proteins }\end{array}$ & $\begin{array}{c}\text { Genomic islets \& } \\
\text { islands, DNA- } \\
\text { restriction/ } \\
\text { modification } \\
\text { system, translation } \\
\text { machinery }\end{array}$ & $\begin{array}{l}\text { Genomic islets \& } \\
\text { islands, DNA- } \\
\text { restriction/ } \\
\text { modification } \\
\text { system, translation } \\
\text { machinery }\end{array}$ & $\begin{array}{l}\text { Hypotheticals } \\
\text { and plasmid- } \\
\text { related genes }\end{array}$ & $\begin{array}{l}\text { Genomic islets \& } \\
\text { islands, DNA- } \\
\text { restriction/ } \\
\text { modification } \\
\text { system, translation } \\
\text { machinery }\end{array}$ & $\begin{array}{l}\text { EPS/LOS } \\
\text { synthesis \& } \\
\text { flagella } \\
\text { modification }\end{array}$ & $\begin{array}{l}\text { Genomic islets \& } \\
\text { islands, DNA- } \\
\text { restriction/ } \\
\text { modification } \\
\text { system, translation } \\
\text { machinery }\end{array}$ \\
\hline
\end{tabular}

${ }^{\dagger}$ Without a pseudogene qualifier

*Plasmids have been identified and/or sequenced in many other strains, reviewed in ref. [35]. 
searching of the $H$. mustelae genome with the Alien Hunter program initially identified 23 candidate regions with anomalous nucleotide content, none of these are large enough to be considered an island or islets (data not shown), and they are not characterized by linkage to phage genes, integrases or tRNA genes. A representative example is the region from HMU08130 to HMU08170 with a GC content of $41.55 \mathrm{~mol} \%$, flanked by direct repeat sequences in HMU08130 and HMU0818; this region encodes a presumptive type I restriction-modification system. The region from HMU08300 to HMU08350 has a GC mol\% content of $46.69 \%$ and harbours several biosynthesis genes that are also found in H. pylori, $H$. hepaticus, W. succinogenes and C. jejuni. Alien Hunter also detected the primary Hsr locus from HMU08520 to HMU08780. Analysis of the GC mol\% content around the genome (Fig. 1) shows several smaller stretches of anomalous GC content, similar to localized deviations in H. pylori. However, there is no evidence for a pathogenicity island in $H$. mustelae, in contrast to $H$. pylori and $H$. hepaticus. A curious feature of the $H$. mustelae genome is the asymmetric nature of the GC skew pattern ([G-C]/[G+C]; Fig. 1). The pattern of GC skew is normally symmetrical for bacterial circular chromosomes [55]. The lack of symmetry of the H. mustelae GC skew may be indicative of recent genome rearrangement, as suggested for Yersinia pestis [56]. This is most likely to be a localized deletion, since in contrast to $Y$. pestis, the GC skew pattern of the $H$. mustelae genome does not suggest a transposed genome region. Lack of large-scale synteny between helicobacter genomes (see Comparative Genomics below) complicates identification of such a presumptive deleted region.

The paucity of insertion sequence elements and bacteriophage-related genes in $H$. mustelae (Table 1) suggests that these mechanisms are not significant agents of diversity generation in this species, a process which is driven in $H$. pylori by free recombination [57]. Thus it was surprising to identify a CRISPR locus and three cas genes (HMU00230-00250) in the H. mustelae genome, as these features have recently been identified as a phage resistance mechanism [58]. CRISPR loci have not been annotated in other helicobacter or campylobacter genomes. HMU00670 encodes another potential phage resistance mechanism, a predicted Abortive Infection (Abi) protein. H. acinonychis is unusual in having two complete prophages in its genome (one of which is no longer contiguous, due to genome decay), which has been attributed in part to the presence of only six predicted functional restriction-modification loci compared

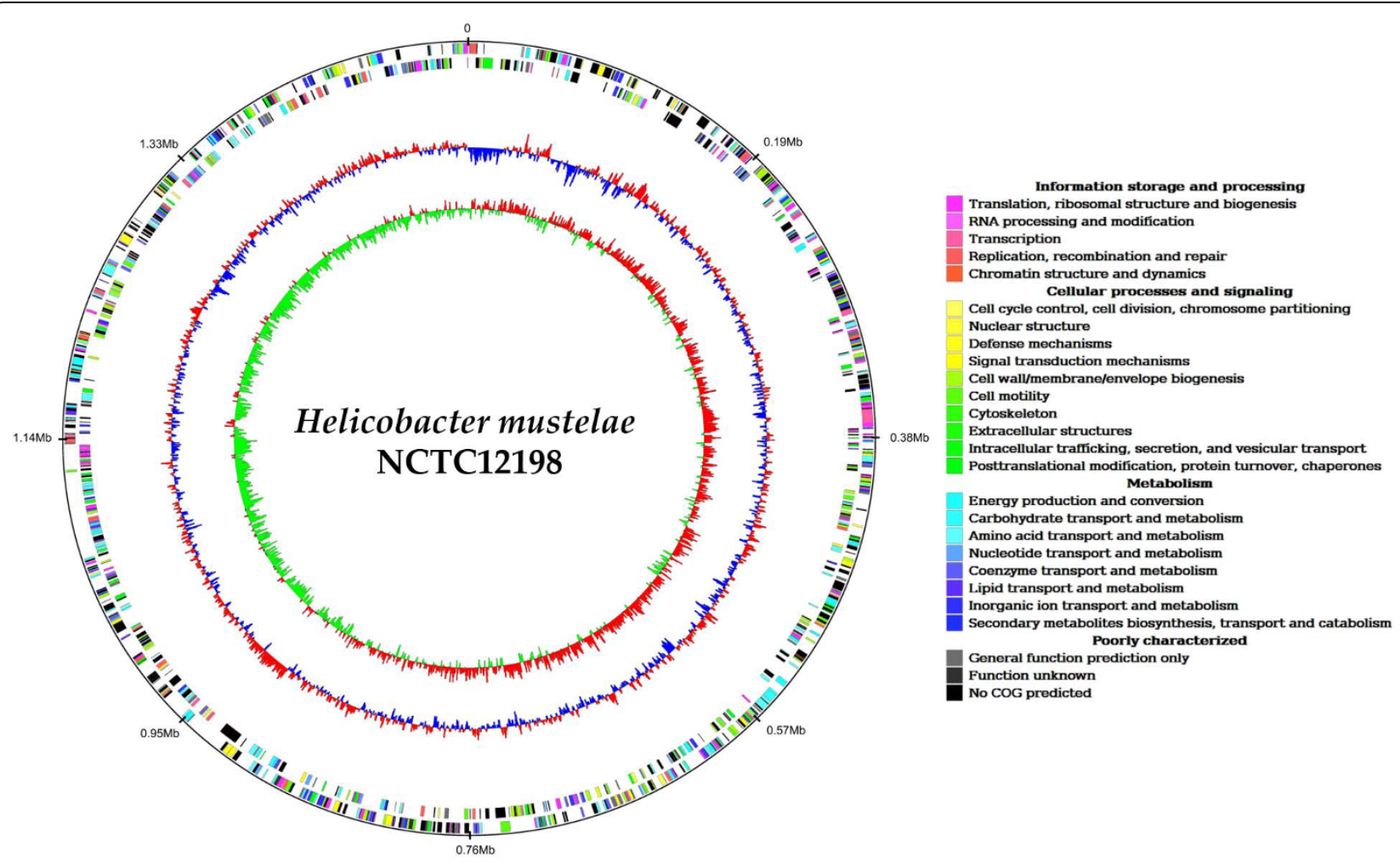

Figure 1 Circular genome atlas of $\boldsymbol{H}$. mustelae. Rings: 1, Nucleotide co-ordinates in megabase pairs; 2, ORF distribution, plus strand; 3, ORF distribution, negative strand; 4, GC\% deviation; 5, GC skew. ORFs are coloured as per colour palette based on COG classifications. 
to eleven in H. pylori [30]. The H. mustelae genome also encodes 6 predicted restriction-modification systems.

\section{Virulence-related Genes in $\mathrm{H}$. mustelae}

Members of the Campylobacterales whose genome has been sequenced to date harbour a variable complement of known or inferred virulence factors genes (reviewed comparatively in ref. [35]). Many of these factors have not actually been studied for biological significance except in $H$. pylori, where the linkage to gastric colonization or pathogenesis for some defined traits is generally very clear [2]. The presence in the $H$. mustelae genome of homologues to genes whose products have been linked to colonization, persistence or pathogenesis in related organisms is summarized in Table 2. As noted above, a cag pathogenicity island is not present. Relative to $H$. pylori, the $H$. mustelae genome contains a second (additional) urease operon AB2, that contributes to acid resistance [41]. There is no full-length $H$. mustelae ortholog of the vacuolating cytotoxin VacA of H. pylori. Homology searches with the H. pylori vacA gene identified 10 predicted autotransporter (AT) genes, organized into three cluster, plus the Hsr locus, and one singleton HMU08270 (Additional File 1). HMU04240 is a VacA homologue that lacks an autotransporter domain. Significantly, when the autotransporter betabarrel domain is excluded from the analysis, six of the VacA homologues detected using the full length VacA sequence (HMU00600, HMU00620, HMU00630, HMU01180, HMU01190 and HMU08270 show no significant identity between their passenger domains and database entries. HMU06680 and HMU06730 are annotated as glycine-rich autotransporters, located in AT cluster 3. Regions of HMU06680 display 32\% identity to HP0922 (a toxin-like outer membrane protein/VacA paralog) and significant residue identity in the passenger domain to an immunodominant antigen in $H$. bilis (accession AAQ14336). In addition, two regions of the HMU06680 protein, residues $100-130$ and 1339-1494, show ca. $25 \%$ residue identity to passenger-domain regions of VacA, and VacA-like proteins in $H$. pylori. Several older studies have suggested that $H$. mustelae does not produce vacuolating cytotoxic activity $[59,60]$, so the biological significance of these VacA-related proteins is unclear. Of the remaining autotransporters, one is the Hsr variable surface antigen HMU08630, in a genetic configuration similar to strain 4298, flanked by cassettes for alternative epitopes [44]. The predicted autotransporter HMU08270 comprises 4,094 amino acids, has no significant identity to database entries, and an unusual autotransporter domain, which is not at the extreme carboxy-terminus. Finally HMU06740 lacks a predictable signal peptidase cleavage site, and is unusually small for an autotransporter protein. The distinctive wealth of this class of secreted protein in $H$. mustelae, the evidence for their production (see below) and the likelihood of their involvement in host interaction, make this bacterium a potentially productive model for exploring autotransporter evolution and biological function.

Table 2 Presence of genes related to colonization, persistence or pathogenesis in the $H$. mustelae genome, compared to $H$. pylori

\begin{tabular}{|c|c|c|c|}
\hline Trait & H. pylori locus & Orthologous $H$. mustelae system & Comments \\
\hline $\begin{array}{l}\text { Cag } \\
\text { pathogenicity }\end{array}$ & cag PAl & absent & Cag PAl linked to severity of pathology and disease \\
\hline $\begin{array}{l}\text { Urease } \\
\text { production }\end{array}$ & Urease operon (ure) & $\begin{array}{l}\text { UreAB and UreAB2 loci (HMU03050-030110) } \\
\text { and HMU13010-13020) }\end{array}$ & Contributes to acid resistance \\
\hline $\begin{array}{l}\text { Vacuolating } \\
\text { cytotoxin }\end{array}$ & $\operatorname{vac} A$ & absent & Cytotoxicity including T-cell inhibition \\
\hline Autotransporters & VacA and paralogs & 10 genes including Hsr locus (Fig. S1) & $\begin{array}{l}\text { Two proteins with low identity to VacA; others - } \\
\text { function unknown }\end{array}$ \\
\hline $\begin{array}{l}\text { Outer membrane } \\
\text { adhesins }\end{array}$ & $\begin{array}{l}\text { Hop, Hor, Hof, Hom } \\
\text { paralogue families }\end{array}$ & No orthologs of BabA, SabA, OipA or AlpA/B. & $\begin{array}{l}\text { Three OMPs related to Hof family; function unknown; } \\
\text { three Hor-Hom homolgues }\end{array}$ \\
\hline Invasion antigen & None & CiaB HMU0700 & C. jejuni homolog enhances cell invasion \\
\hline $\begin{array}{l}\text { Neutrophil } \\
\text { activation }\end{array}$ & NapA & HMU1269 & $\begin{array}{l}\text { Activates neutrophils \& contributes oxidative stress } \\
\text { resistance }\end{array}$ \\
\hline HpaA & HP0797 & absent & Putative adhesin and flagellum sheath lipoprotein \\
\hline Motility & $\mathrm{Fla} / \mathrm{Flg} / \mathrm{Fli} / \mathrm{Flh}$ & $\mathrm{Fla} / \mathrm{Flg} / \mathrm{Fli} / \mathrm{Flh}$ & Motility is required for gastric colonization \\
\hline $\begin{array}{l}\text { Collagenase } \\
\text { secretion }\end{array}$ & HP0169 & HMU02630 & Required for $\mathrm{H}$. pylori colonization of Mongolian gerbi \\
\hline $\begin{array}{l}\text { Adhesion/tissue } \\
\text { damage }\end{array}$ & - & HMU00160-HMU00170 Hag/Hly & Putative haemagglutinin/haemolysin \\
\hline $\begin{array}{l}\text { Plasminogen } \\
\text { binding }\end{array}$ & HP0508 & HMU02820; HMU09010 & Could enhance tissue damage by proteolysis \\
\hline
\end{tabular}


Outer membrane proteins are important for the pathogenesis of $H$. pylori. The genome of $H$. mustelae contains 26 genes that were annotated as encoding putative outer membrane proteins. Phylogenetic analysis of these proteins relative to the categorized $H$. pylori OMPs [61] showed that some of the $H$. mustelae OMPs group with H. pylori orthologs (Fig. 2). For example HMU05640, HMU05650, and HMU10680 convincingly cluster in the clade containing the 8 members of the Hof OMP family of $H$. pylori, and the three Hof-related $H$. mustelae proteins show similar size and $\mathrm{C}$-terminal motif to the H. pylori Hof proteins (Table 3 ). Apart from the fact that HP0486 is expressed and is not heat-modifiable [62], suggesting it is not a porin, nothing is known about the function of Hof proteins. Interestingly, a further $12 \mathrm{H}$. mustelae OMPs cluster in two groups either side of the Hof protein clade (Fig. 2). None of the annotated $H$. mustelae OMP sequences position phylogenetically in the tight Hop-containing clade that includes BabA, SabA and OipA, and orthologs of these three adhesins are absent in the $H$. mustelae genome. One Omp in H. mustelae, HMU04150, is positioned on the periphery of a clade containing both Hor and Hop proteins of $H$. pylori (Fig. 2). However HMU04150 lacks the characteristic (AEX [D, N]G) motif present in the H. pylori Hop proteins, and its carboxy terminal motif (Table 3) is more similar to Hor proteins. HMU11950 clusters with the three FecA orthologues of $H$. pylori. The majority of the remaining $H$. mustelae OMPs are currently unclassified (Table 3). They almost all share the properties of relatively small size, and lack of significant-identity database homologues. Some have atypical carboxy terminal sequences for OMPs, and signal peptidase cleavage sites that are not readily predicted. Two of them are expressed (see below), indicating significant production levels, and the biological function of these unclassified OMPs warrants further investigation.

The $H$. mustelae genome encodes many other proteins likely to contribute to virulence, based upon information available for homologues (Table 2). Close to the origin of replication, in a region distinguished by anomalously low GC content, are two genes related to haemolysis or haemagglutination. HMU00160 encodes a predicted protein with significant homology to haemolysin activators of diverse gram-negatives including Photorhabdus luminescens, Burkholderia pseudomallei, and a pathogenicityisland encoded determinant of E. coli [63]. HMU00170 Hag/Hly encodes a predicted $227 \mathrm{kDa}$ protein with predicted signal peptide, and containing Pfam motifs for haemagglutination (Haemagg_act; PF05860), filamentous haemagglutinin (Fil_haemagg; PF05594), and an ATP/ GTP-binding site motif A (P-loop). Homologues of this protein constitute a large family whose members are widely distributed among gram-negative pathogens, are annotated as either haemagglutinins or haemolysins, but which appear to lack functional characterization. The residue identity with HMU00170 is confined to the first 350 residues of that protein, and is particularly high over the filamentous haemagglutinin region (ca. 35-50\% identity). Homologues of this pair of genes are lacking in helicobacters and campylobacters, suggesting this is an $H$. mustelae-specific acquisition among the $\varepsilon$-proteobacteria.

H. mustelae has two orthologs (HMU02820 and HMU09010) of HP0508, which has been characterized as a plasminogen binding protein in $H$. pylori [64]. The biological significance of this phenotype in either gastric pathogen is unclear. HMU0700 was annotated as CiaB by virtue of containing a low molecular weight phosphotyrosine protein phosphatase Pfam domain, and significant residue identity to the $C$. jejuni $\mathrm{CiaB}$ (Campylobacter Invasion Antigen B; Cj0914c) protein. This protein is required for maximal invasion of epithelial cells by $C$. jejuni, and is notably exported by the flagellar export apparatus [65]. Another recently discovered Cia protein, $\mathrm{Cj} 1242$ [66], is not present in the $H$. mustelae genome. Homologues of $\mathrm{CiaB}$ have been annotated in W. succinogenes and $H$. hepaticus, but not in $H$. pylori, which is curious because $\mathrm{CiaB}$ is also present in $\varepsilon$-proteobacteria isolated from sea vents [67], which are located on the deepest branch of the $\varepsilon$-proteobacterial tree. Like $H$. pylori, $H$. mustelae lacks the $\mathrm{N}$-glycosylation system that contributes to pathogenesis in Campylobacters [68,69], and the genes for which are also present in $H$. hepaticus, $W$. succinogenes and sea vent $\varepsilon$-proteobacteria [67]. HMU10120 is a homologue of proteins in other Campylobacterales which was first described in C. jejuni as PEB4a, and which is a major antigen and cell adhesin [70,71]. The HMU10120 gene product was detected in the $H$. mustelae proteome (see below). Its role as an adhesin warrants further scrutiny, since it surprisingly contains a rotamase Pfam domain. Another candidate virulence/survival determinant in H. mustelae is HMU12690, which is a homologue of the $H$. pylori neutrophil activating protein HP0243 [72]. This has recently been described as one of three $H$. pylori proteins diagnostically predictive for development of gastric cancer [73]. NapA also has a role in protecting $H$. pylori from oxidative stress [74]. These features, coupled with the high-level expression of the HMU12690 protein in H. mustelae (see below), suggest that it may be relevant for survival or pathogenesis in the ferret stomach. The H. mustelae gene HMU06150 is homologous to $\mathrm{Cj} 1327$ and $\mathrm{Cj} 1328$, two genes involved in sialic acid biosynthesis, HMU06140 is annotated as an acylneuraminate cytidylyltransferase. Thus, H. mustelae may decorate its surface with sialic acid. 


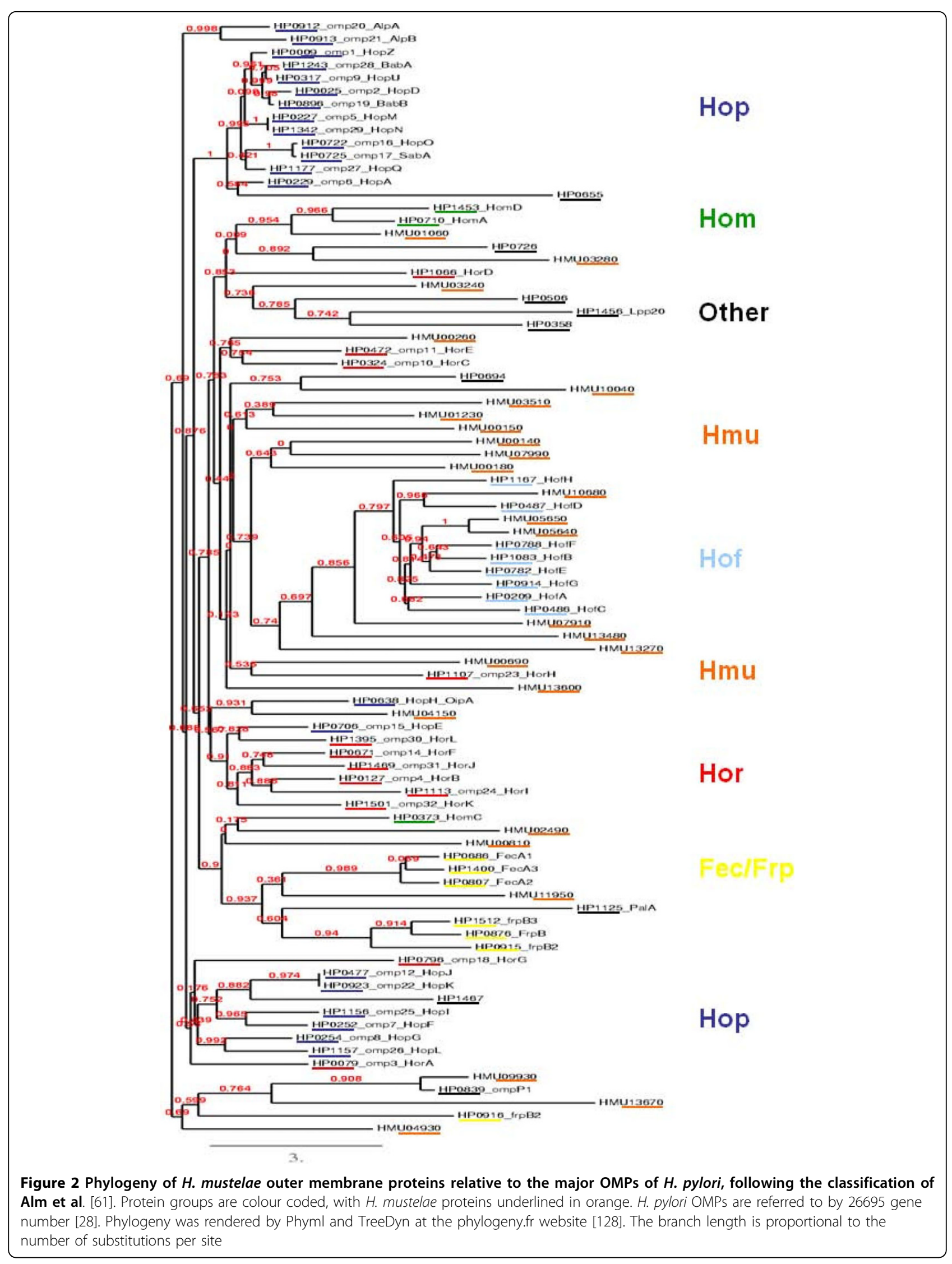


Table 3 Classification of $\boldsymbol{H}$. mustelae outer membrane proteins in relation to $\boldsymbol{H}$. pylori OMPs

\begin{tabular}{|c|c|c|c|c|c|c|}
\hline Gene & $\begin{array}{l}\text { Protein length } \\
\text { (AA) }\end{array}$ & $\begin{array}{l}\text { Predicted MW } \\
\text { (Da) }\end{array}$ & $\begin{array}{c}\mathrm{N} \text {-terminal signal } \\
\text { motif }^{\dagger}\end{array}$ & $\begin{array}{c}\text { C-term } \\
\text { motif }\end{array}$ & FASTA Smith-Waterman identity* & $\begin{array}{c}\text { Detected in } \\
\text { proteome }\end{array}$ \\
\hline \multicolumn{7}{|l|}{$\begin{array}{l}\text { Hof-related } \\
\text { OMPs }\end{array}$} \\
\hline HMU05640 & 456 & 51,804 & A $\downarrow M D F$ & -YSF & $\begin{array}{c}32.1 \% \text { in } 479 \text { aa overlap with H. pylori } \\
\text { HofB (HP1083) }\end{array}$ & Yes \\
\hline HMU05650 & 451 & 51,181 & $\mathrm{~A} \downarrow V E T$ & $-Y G F$ & $\begin{array}{c}\text { 36.2\% in } 496 \text { aa overlap with H. pylori } \\
\text { HofF (HP0788) }\end{array}$ & Yes \\
\hline HMU10680 & 447 & 50,681 & $\mathrm{~A} \downarrow$ ASS & -YFF & $\begin{array}{c}\text { 29.3\% in } 474 \text { aa overlap with H. pylori } \\
\text { HofE (HP0782) }\end{array}$ & No \\
\hline \multicolumn{7}{|l|}{$\begin{array}{l}\text { Hop-related } \\
\text { OMP }\end{array}$} \\
\hline HMU04150 & 189 & 20,863 & $R \downarrow A Y D ?$ & - YSF & $34.7 \%$ in 170 aa overlap with HP0608 & No \\
\hline \multicolumn{7}{|l|}{$\begin{array}{l}\text { FecA-related } \\
\text { OMP }\end{array}$} \\
\hline HMU11950 & 220 & 25,230 & $?$ & - ENP & No significant homologues & No \\
\hline \multicolumn{7}{|l|}{$\begin{array}{l}\text { Unclassified } \\
\text { OMPS }\end{array}$} \\
\hline HMU00140 & 232 & 26,345 & $\mathrm{G} \downarrow A G T$ & $-F L F$ & No significant homologues & No \\
\hline HMU00150 & 252 & 28,374 & $A \downarrow K E D$ & $-\| F$ & No significant homologues & No \\
\hline HMU00180 & 242 & 27,650 & unclear & $-\mathrm{YVF}$ & No significant homologues & No \\
\hline HMU00690 & 208 & 22,360 & $A \downarrow E A l$ & -YTF & No significant homologues & No \\
\hline HMU00810 & 135 & 15,492 & $A \downarrow L V D$ & $-\mid R Y$ & No significant homologues & No \\
\hline HMU01060 & 316 & 34,414 & $E \downarrow A T K$ & -WYF & $\begin{array}{c}\text { 39.7\% in } 194 \text { aa overlap with HomD } \\
\text { (HP1453) }\end{array}$ & No \\
\hline HMU02490 & 469 & 51,412 & $A \downarrow G K L$ & $-Y N F$ & No significant homologues & No \\
\hline HMU03240 & 394 & 32,308 & $A \downarrow \mid E N$ & $-F Y F$ & 34.5 in 281 aa overlap with HP0726 & No \\
\hline HMU03280 & 282 & 25,467 & unclear & $-K F F$ & No significant homologues & No \\
\hline HMU03510 & 162 & 17,686 & V\SPE & $-\mathrm{VEF}$ & No significant homologues & No \\
\hline HMU04930 & 899 & 98,821 & A $\backslash Y N P ?$ & $-W V F$ & $\begin{array}{c}\text { 27.2\% in } 913 \text { aa overlap with HomC } \\
\text { (HP0373) }\end{array}$ & No \\
\hline HMU07910 & 873 & 98,252 & $\mathrm{~A} \downarrow N E I$ & $-\mathrm{YHF}$ & $\begin{array}{c}\text { 32.0\% in } 443 \text { aa overlap with HofD } \\
\text { (HP0487) }\end{array}$ & No \\
\hline HMU09930 & 565 & 62,131 & $V \downarrow A G A$ & -YHW & $\begin{array}{l}\text { 55\% in } 586 \text { aa overlap with OmpP1 } \\
\text { (HP0839) }\end{array}$ & No \\
\hline HMU13480 & 258 & 28,279 & $A \downarrow T K G ?$ & - LIY & $32.0 \%$ in 259 aa overlap with HH_1629 & No \\
\hline HMU13600 & 190 & 21,548 & A $\downarrow M T L$ & - EAK & No significant homologues & Yes \\
\hline HMU13670 & 173 & 19,128 & $\mathrm{~A} \downarrow K T C$ & $-\mathrm{NIK}$ & No significant homologues & Yes \\
\hline HMU13270 & 236 & 27,193 & $\downarrow$ & $-\mathrm{NHL}$ & No significant homologues & No \\
\hline HMU00260 & 196 & 21,989 & $A \downarrow H A R ?$ & $-F V F$ & No significant homologues & No \\
\hline HMU07990 & 343 & 39,155 & A $\downarrow E N L$ & $-F A F$ & 42.9\% in 233 aa overlap with HP0694 & No \\
\hline HMU10040 & 167 & 18,839 & $\downarrow$ & $-E G K$ & 50.9\% in 163 aa overlap with HP1546 & No \\
\hline HMU01230 & 232 & 24,626 & A $\downarrow$ NTN & $-\mathrm{YKF}$ & 44.5\% in 236 aa overlap with HH_0525 & No \\
\hline
\end{tabular}

†Predicted by SignalP $2.0 \mathrm{HMM}$ with confidence, with low confidence (?), or not predicted (unclear).

${ }^{*}$ Only homologies with E-value $<10^{-10}$ presented.

H. pylori incorporates human blood group antigens into its LPS (reviewed in references [75-77]) in a strain dependent manner. Ferrets express a structure equivalent to human blood group A on gastric tissue, and $H$. mustelae strains express blood group A antigen in their LPS $[47,78]$. The $H$. mustelae genome includes divergent orthologues of ten out of fourteen genes [77] implicated in H. pylori LPS biosythesis/blood group antigen production (Additional File 2). Some of these candidate orthologues are so divergent that they cannot be confidently separated from potential flagellin glycosylation genes (see below). The $H$. mustelae repertoire includes a single predicted fucosyl transferase, encoded by HMU12060. H. pylori fucosyltransferases display low identity to mammalian enzymes. Interestingly, HMU12050 encodes a predicted blood group AB glycosyltransferase, which shows 31-33\% BLAST identity against mammalian $\mathrm{AB}$ glycosyltransferases, and putative 


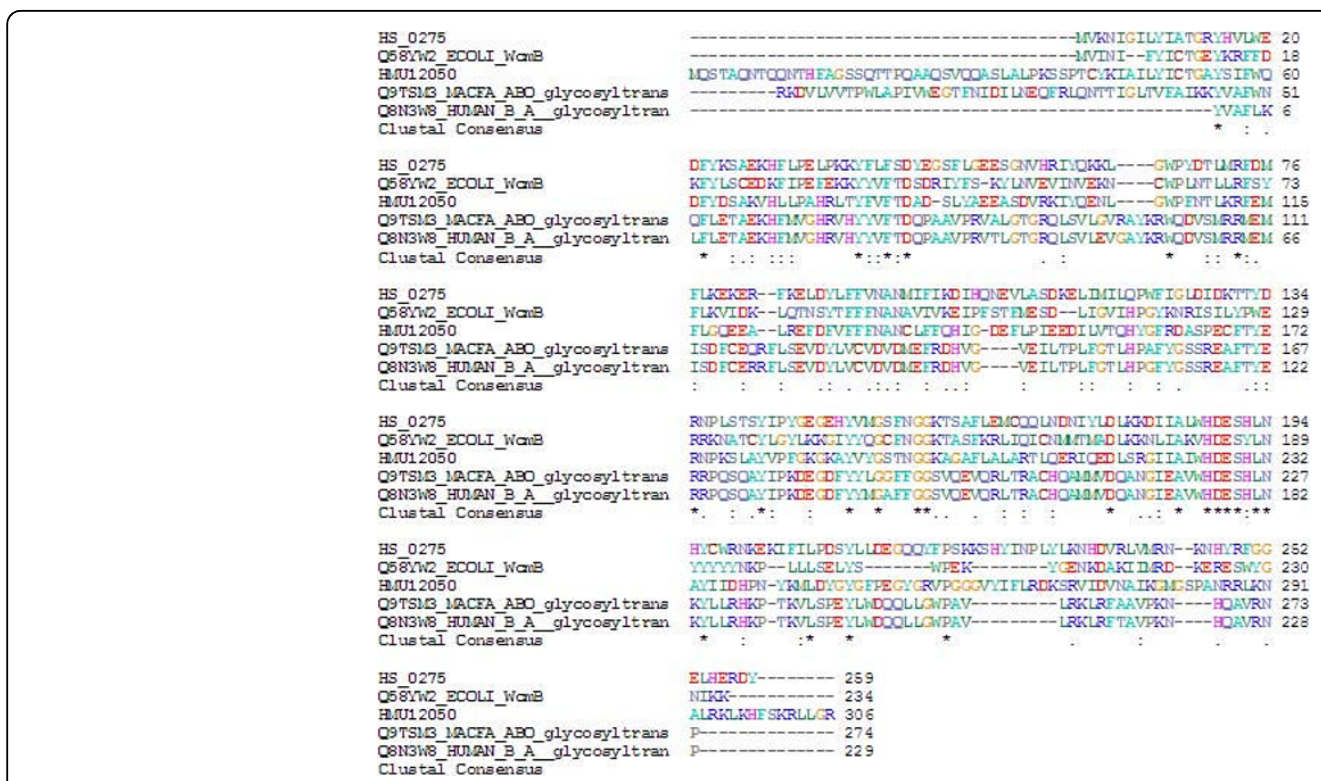

Figure 3 ClustalW alignment of the HMU12050-encoded protein with homologues in Haemophilus somnus; E. coli (WcmB), Macaca fascicularis ABO glycoysltransferase; Homo sapiens AB glycosyltransferase.

glycosyltransferases from E. coli O86 and Haemophilus somnus (Fig. 3). To our knowledge, this is the first identification of a bacterial gene for synthesizing mammalian blood group A/B antigen which is known to be actually produced on the bacterial surface. It is expected by analogy with H. pylori (reviewed in ref. [75]) that this gene product will contribute to the ability of $H$. mustelae to adapt to the gastric environment (immune avoidance), modulate inflammation and immune cell recognition, and exacerbate pathology by triggering autoimmunity. The ferret model provides an excellent platform to test these hypotheses.

There are 4 secretion systems predicted in the $H$. mustelae genome (see below), including the flagellum protein export system. Motility conferred by flagella is an essential property for successful colonization of the ferret by $H$. mustelae [79], and the hook and flagellin proteins of $H$. mustelae have already been characterized $[45,46]$. The annotation of the $H$. mustelae genome revealed a typical set [80] of Campylobacterales flagellar genes (Additional File 3), for structural components, glycosylation, regulation, and chemotaxis. The number of chemotaxis genes is reduced compared to $H$. pylori, with orthologs of $c h e V 1, t l p C$, and $t l p A$ apparently being absent. This may be functionally offset by the presence of HMU05990, a putative MCP-type signal transduction protein, which includes a PAS domain sensor sequence (Pfam 08447). This protein is absent in H. pylori and $H$. hepaticus, and its closest homolog is in C. jejuni. H. pylori contains several genes including HP0840 and HP0366, whose products result in glycosylation of flagellin with pseudaminic acid [81], which is required for flagellin assembly into flagellar filaments [82]. The $H$. mustelae genome includes a clear orthologue of HP0840 (designated flaA1; Additional file 2, Table S2). Two potential homologues of HP0366, HMU06610 and HMU02370, were identified in the $H$. mustelae genome. Another group of $H$. mustelae genes, HMU11700HMU11730, shows some relatedness to Cj1311-Cj1317, involved in flagellin sialylation, but their function, and indeed the glycosylation state of $H$. mustelae flagellins, is still unknown. A noteworthy feature is the fact that two essential motility genes, fliK (HMU07800; hook length control protein) and motA (HMU03580; motor protein) are pseudogenes in the sequenced strain, which we subsequently confirmed to be non-motile (data not shown). The original type strain used for the species description emendation [17] was motile, as are H. mustelae isolates from wild ferrets [18]. In the case of FliK, HMU07800 is flanked upstream by an ORF encoding 277 amino acids, which is preceded by a perfect GG$\mathrm{N}_{10}$-GC $\sigma^{54}$ promoter motif expected for fliK $[83,84]$. Thus, a frame-shift between HMU07800 and HMU07790 has inactivated $f l i K$. The gene for MotA also appears to have suffered a frameshift. We assume that these mutations occurred during recent laboratory passage, in a manner similar to frame-shift inactivation of fliP in H. pylori strain 26695 [85], revertants of which can be easily obtained on motility agar at high plating density.

The 3 other complete or partial protein secretion systems predicted from the $H$. mustelae genome are 
presented in Additional File 4. The Sec system genes are not linked, except for $\sec D$ and $\sec F$, which are clustered with yajC. Like other $\varepsilon$-proteobacteria, $H$. mustelae lacks $\mathrm{SecB}$; it has a single $\sec A$ gene. The $\sec E$ gene was found by homology search, internal to the $t l p$ gene and in the opposite strand. There is a single tatB-tatC gene cluster. The tatA gene is present (HMU02290) but the tat $E$ gene is apparently absent. It is thus not clear if the H. mustelae Tat system is functional. Relevant for the abundance of autotransporters, we annotated a gene predicted to encode an Omp85(YaeT) homolog, which has a critical role in outer membrane protein insertion/ biogenesis [86]. Analysis of the Gsp genes suggested the presence of a fragmented or remnant pilin biosynthesis system. The genes encoding GspDEF (also called CtsDEF) are clustered. However, there are other ORFs around them that have no significant homology to Gsp or type IV pilin-related proteins, except for a putative pseudopilin but this is unusually distantly separated from the others. Putative PilT-encoding and prepilin peptidase genes were also found separately on the chromosome, and not near anything that looks like encoding type IV pili or GSP machinery. Thus there may be a pilin assembly unit in the $H$. mustelae genome, which could contribute to pathogenicity, but functional investigation is required. Types IV and VI secretion system components were not found.

The presence of homopolymeric tracts in and between genes has been identified as a potential antigenic variation mechanism in C. jejuni [31], H. pylori [28] and $H$. hepaticus [29], and has been postulated to compensate for the relative paucity of transcriptional regulators. Disregarding polyA or polyT repeats because of the high genomic AT content, we identified 12 genes potentially affected by variation in copy number of intragenic homopolymers, and 8 potentially affected by intergenic variation (Additional file 5). Only two of the former category showed actual length variation in the shot-gun read data, compared to three of the latter. As expected from other Campylobacterales, the dominant gene function affected was surface architecture, at either protein or carbohydrate level. However, the overall number of genes potentially affected by this putative method of antigenic variation was significantly lower than $H$. pylori, C. jejuni or H. hepaticus. This may be due to the dominant coverage by the Hsr protein, which is a major antigen, and which changes epitopes by recombination [44].

\section{The Expressed Proteome of $\boldsymbol{H}$. mustelae}

We prepared sub-cellular fractions from $H$. pylori and $H$. mustelae, and first compared them by SDS-PAGE (Fig. 4). We cultured both species for two days on plates, compared to five-days used for the initial $H$. pylori proteome analysis [87], to minimize development of coccoid

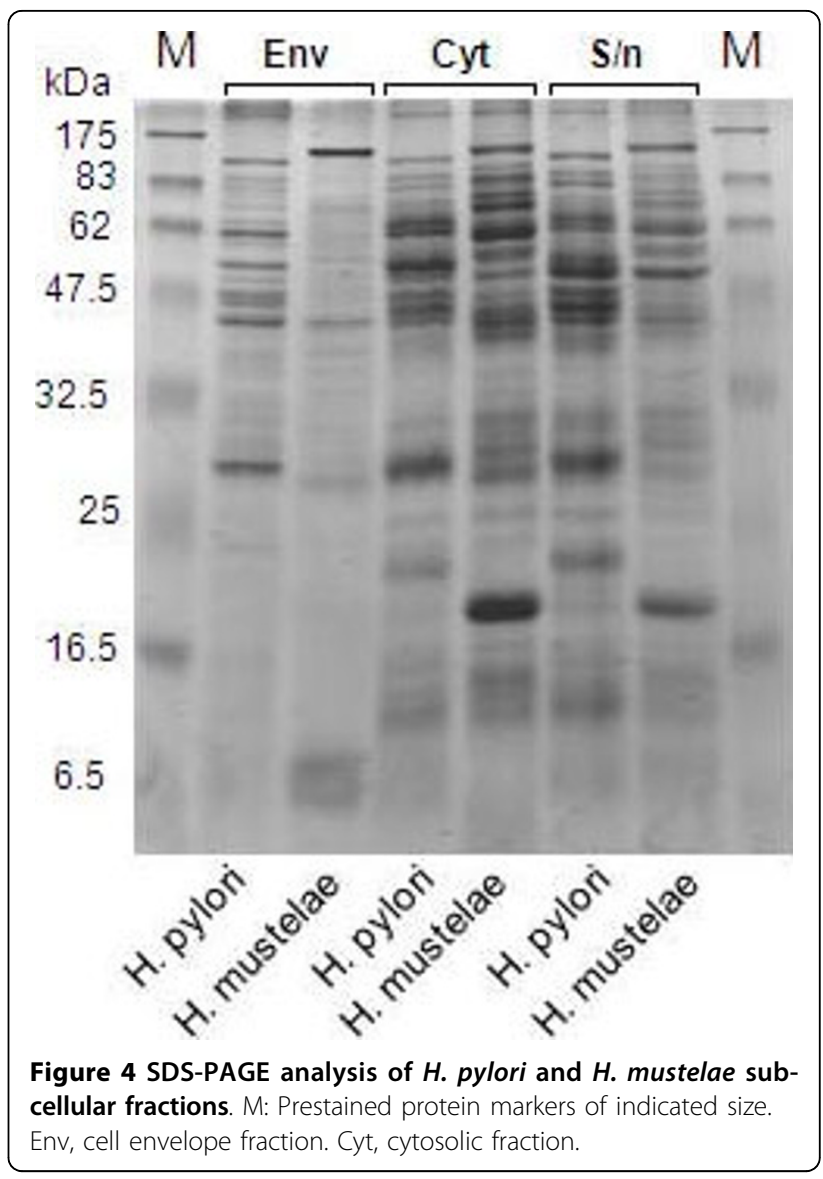

forms [88]. The initial supernatant from harvesting the cells was designated as an extracellular fraction, since it was expected to contain exported proteins. In accordance with the well-documented property of autolysis for H. pylori [89], the extracellular fraction of both species shared many bands with the cytosolic fraction of the respective species (Fig. 4). However, it was also clear that most of the proteins were apparently not shared between the two species. The greatest number of co-migrating bands between species was observed in the cytosol fraction, while the envelope fractions of the two species contained distinctive protein profiles. The $H$. mustelae envelope fraction contained around eight major proteins, less than half the number in the $H$. pylori envelope fraction, and few if any appeared to be produced by both species, consistent with the predictions from their respective genome sequences.

The dominant proteins in the envelope and cytoplasmic compartments of $H$. mustelae were identified by LC-MS. The most abundant 50 proteins in each fraction are presented in Table 4 and Table 5; the complete datasets are available in Additional file 6 and Additional file 7. The membrane proteome includes several cytoplasmic proteins that are also known to be highly 
Table 4 The envelope proteome of $\boldsymbol{H}$. mustelae determined by LC-MS

\begin{tabular}{|c|c|c|c|c|c|c|c|}
\hline $\operatorname{Rank}^{a}$ & Locus & Annotation & $\begin{array}{c}\mathrm{Mw} \\
\mathrm{Da}\end{array}$ & $\begin{array}{l}\text { MOWSE } \\
\text { Score }^{b}\end{array}$ & $\begin{array}{c}\text { Coverage }^{c} \\
\% \\
\end{array}$ & emPAle $^{d}$ & $\begin{array}{c}\text { Mol } \\
\%\end{array}$ \\
\hline 1 & HMU14370 & cft ferritin & 19,056 & 455 & 53 & 2.72 & 5.74 \\
\hline 2 & HMU03320 & ahpC alkyl hydroperoxide reductase & 22,088 & 806 & 68 & 2.48 & 5.22 \\
\hline 3 & HMU12840 & aroQ 3-dehydroquinate dehydratase & 17,477 & 105 & 21 & 2.16 & 4.55 \\
\hline 4 & HMU14250 & $\begin{array}{l}\text { undefined product; COG4969, tfp pilus assembly protein, major pilin PilA [cell } \\
\text { motility and secretion/Intracellular trafficking and secretion] }\end{array}$ & 15,880 & 241 & 50 & 1.42 & 3 \\
\hline 5 & HMU00320 & $\begin{array}{l}\text { undefined product; no putative conserved domains detected, hypothetical } \\
\text { protein Lreu23DRAFT_1924 [L. reuteri 100-23]: 35\% ID }\end{array}$ & 8,942 & 158 & 33 & 1.37 & 2.89 \\
\hline 6 & HMU14210 & fldA flavodoxin 1 & 18,147 & 231 & 25 & 1.31 & 2.76 \\
\hline 7 & HMU03050 & ureA fusion of urease beta and gamma subunits & 25,199 & 683 & 60 & 1.15 & 2.43 \\
\hline 8 & HMU03060 & ureB urease alpha subunit & 61,146 & 1,218 & 37 & 1.048 & 2.21 \\
\hline 9 & HMU04000 & groEL 60 kD chaperonin (cpn60) & 57,443 & 1,714 & 51 & 1.035 & 2.18 \\
\hline 10 & HMU12690 & possible bacterioferritin & 17,198 & 380 & 32 & 1.015 & 2.14 \\
\hline 11 & HMU03500 & putative amino-acid transporter periplasmic solute-binding protein & 30,533 & 626 & 52 & 0.96 & 2.02 \\
\hline 12 & HMU01210 & tpx probable thiol peroxidase & 17,993 & 350 & 38 & 0.83 & 1.75 \\
\hline 13 & HMU00630 & putative autotransporter protein & 151,727 & 1,371 & 25 & 0.82 & 1.73 \\
\hline 14 & HMU13930 & $\begin{array}{l}\text { putative exported protein; COG1464, NIpA, ABC-type metal ion transport } \\
\text { system, periplasmic component/surface antigen [inorganic ion transport and } \\
\text { metabolism] }\end{array}$ & 28,862 & 425 & 30 & 0.82 & 1.73 \\
\hline 15 & HMU01180 & putative membrane-anchored cell surface protein & 281,808 & 2,432 & 22 & 0.81 & 1.72 \\
\hline 16 & HMU03120 & tuf elongation factor TU & 43,570 & 850 & 48 & 0.77 & 1.64 \\
\hline 17 & HMU04030 & petA putative putative ubiquinol-cytochrome $C$ reductase iron-sulfur subunit & 17,916 & 227 & 46 & 0.77 & 1.64 \\
\hline 18 & HMU06410 & $\begin{array}{l}\text { undefined product; No putative conserved domains detected, hypothetical } \\
\text { protein Hac_1480 [Helicobacter acinonychis str. Sheeba]: } 29 \% \text { ID }\end{array}$ & 20,229 & 254 & 18 & 0.77 & 1.64 \\
\hline 19 & HMU03990 & groES 10 kD chaperonin (cpn10) & 10,185 & 157 & 31 & 0.71 & 1.51 \\
\hline 20 & HMU09770 & trxA thioredoxin & 11,553 & 194 & 28 & 0.71 & 1.51 \\
\hline 21 & HMU08630 & putative outer membrane autotransporter & 155,228 & 968 & 14 & 0.64 & 1.37 \\
\hline 22 & HMU05030 & putative hydantoinase $\mathrm{A}$ & 78,444 & 785 & 30 & 0.54 & 1.15 \\
\hline 23 & HMU13940 & $\begin{array}{l}\text { putative exported protein; COG1464: ABC-type metal ion transport system, } \\
\text { periplasmic component/surface antigen [inorganic ion transport and } \\
\text { metabolism] }\end{array}$ & 29,374 & 430 & 29 & 0.54 & 1.15 \\
\hline 24 & HMU05020 & undefined product; COG4647/pfam08882, acetone_carb_G & 14,279 & 213 & 29 & 0.49 & 1.04 \\
\hline 25 & HMU01190 & putative hypothetical glycine-rich autotransporter protein & 194,616 & 1,281 & 19 & 0.48 & 1.02 \\
\hline 26 & HMU00600 & putative LPXTG surface protein & 133,006 & 651 & 14 & 0.47 & 1 \\
\hline 27 & HMU09610 & secG putative protein-export membrane protein & 12,734 & 81 & 21 & 0.46 & 0.98 \\
\hline 28 & HMU12860 & sodB superoxide dismutase (Fe) & 24,576 & 231 & 23 & 0.46 & 0.98 \\
\hline 29 & HMU14090 & putative thioredoxin & 11,796 & 138 & 30 & 0.46 & 0.98 \\
\hline 30 & HMU11370 & $\begin{array}{l}\text { undefined product; no putative conserved domains detected, hypothetical } \\
\text { protein Abu_2077 [Arcobacter butzleri RM4018]: 37\% }\end{array}$ & 7,677 & 92 & 26 & 0.46 & 0.98 \\
\hline 31 & HMU05010 & putative hydantoin hydantoinase A & 70,769 & 835 & 31 & 0.45 & 0.96 \\
\hline 32 & HMU10410 & rpsH 30 S ribosomal protein 58 & 14,807 & 247 & 32 & 0.43 & 0.91 \\
\hline 33 & HMU10080 & putative putative membrane protein & 10,902 & 103 & 17 & 0.42 & 0.89 \\
\hline 34 & HMU04360 & atpC ATP synthase F1 sector epsilon subunit & 13,211 & 108 & 16 & 0.42 & 0.89 \\
\hline 35 & HMU04350 & atpD ATP synthase F1 sector beta subunit & 51,310 & 581 & 23 & 0.42 & 0.89 \\
\hline 36 & HMU10380 & rpsE 30 S ribosomal protein S5 & 15,592 & 199 & 33 & 0.42 & 0.89 \\
\hline 37 & HMU09160 & $\begin{array}{l}\text { undefined product; no putative conserved hits detected, hypothetical protein } \\
\text { HH1743 [Helicobacter hepaticus ATCC 51449]: } 32 \% \text { ID }\end{array}$ & 43,936 & 335 & 14 & 0.40 & 0.85 \\
\hline 38 & HMU10290 & rpoA DNA-directed RNA polymerase alpha chain & 37,551 & 320 & 24 & 0.38 & 0.82 \\
\hline 39 & HMU05040 & putative hydantoin utilization protein B & 83,272 & 514 & 23 & 0.37 & 0.8 \\
\hline 40 & HMU05840 & putative flagellin & 53,982 & 501 & 27 & 0.37 & 0.79 \\
\hline 41 & HMU10120 & peb4[1]f2 major antigenic peptide PEB3ll binding factor 2 & 31,816 & 371 & 32 & 0.35 & 0.76 \\
\hline 42 & HMU04050 & petC putative ubiquinol-cytochrome $C$ reductase cytochrome $C$ subunit & 33,425 & 299 & 25 & 0.35 & 0.74 \\
\hline 43 & HMU04380 & exbD3 exbD olR family transport protein & 14,662 & 132 & 23 & 0.35 & 0.74 \\
\hline
\end{tabular}


Table 4: The envelope proteome of $\boldsymbol{H}$. mustelae determined by LC-MS (Continued)

\begin{tabular}{|c|c|c|c|c|c|c|c|}
\hline 44 & HMU06080 & $\begin{array}{l}\text { hypothetical protein Cj0372; COG0754/pfarm03738: Glutathionylspermidine } \\
\text { synthase [amino acid transport and metabolism] }\end{array}$ & 44,843 & 197 & 12 & 0.35 & 0.74 \\
\hline 45 & HMU11040 & fliL possible flagellar protein & 18,741 & 175 & 18 & 0.33 & 0.7 \\
\hline 46 & HMU04330 & atpA ATP synthase F1 sector alpha subunit & 55,012 & 371 & 20 & 0.31 & 0.67 \\
\hline 47 & HMU07380 & hupB DNA-binding protein HU homolog & 10,122 & 142 & 26 & 0.29 & 0.61 \\
\hline 48 & HMU03350 & rplS 50 S ribosomal protein L19 & 13,546 & 226 & 28 & 0.29 & 0.61 \\
\hline 49 & HMU03180 & rplL 50 S ribosomal protein $L 7 / L 12$ & 12,946 & 97 & 18 & 0.27 & 0.58 \\
\hline 50 & HMU01920 & htrA serine protease (protease DO) & 45,914 & 305 & 17 & 0.27 & 0.58 \\
\hline
\end{tabular}

The 50 most abundant proteins are tabulated.

a. Relative abundance ranked by mol\%

b. Score for the entire protein derived by MASCOT, and made up of the individual scores given to each peptide sequence

c. Proportion of each protein sequence identified

d. Exponentially modified protein abundance index. See Methods for details and reference.

expressed in $H$. pylori, including alkyl hydroperoxide reductase $\mathrm{AhpC}$, flavodoxin and thioredoxin [87], and bacterioferritin [90]. Resistance to oxidative stress, and electron transfer functions, are clearly important processes that are performed using similar proteins in the two species. These proteins are all known to form either higher molecular weight aggregates, or membrane associations, which may explain their presence in the insoluble cell fraction. The AhpC protein, originally and mistakenly thought to be $H$. pylori-specific [91], was reported to be produced by several other Helicobacter species but not $H$. mustelae [92], although the gene was detectable in $H$. mustelae by PCR. The abundant soluble urease subunits $\mathrm{A}$ and $\mathrm{B}$ were also present in the insoluble fraction, as well as the cytosolic fraction, either through aggregation or membrane association in the former. The UreA2 and UreB2 structural sub-units were not detected, even though their mass fingerprints are clearly distinguishable from UreA and UreB (not shown). This non-production under our growth conditions is consistent with the observation that the expression of the Ure2 operon in $H$. mustelae only occurs under nickel limitation [41]. Despite the apparent lack of similarity between the $H$. pylori and $H$. mustelae proteomes in one-dimensional electrophoresis, when the 20 most abundant proteins detected in $H$. pylori by two-dimensional electrophoresis [87] were cross-compared to the $H$. mustelae cytosolic proteome, all 20 were present in the latter sample (Table 6 ). The relative abundances cannot be reliably compared due to differences in the methodologies, and growth phases of cells. The shorter growth period we used is reflected by the lower levels of stress proteins and higher levels of elongation factor EF-Tu in the detected $H$. mustelae proteome. Future comparative transcriptomic and proteomic investigations are needed to identify variations in core genome expression between the two species. In addition, we will compare the $H$. mustelae transcriptome and proteome after 5 days growth to that of $H$. pylori, to clarify comparative issues with the current datasets.

The abundant members of the cell envelope proteome include proteins involved in metabolism (e.g. ATP synthase), transport (e.g. ABC transporter subunits), secretion (SecG, lower amounts of SecA), and several flagellar proteins (Table 4). Notable among the most abundant proteins is HMU14250, a hypothetical protein with homology to pseudopilin or pilin subunits (see above). Less than $1 \%$ of the expressed cytosolic proteome was annotated as "hypothetical". In contrast, six of the top fifty proteins in the membrane proteome were annotated as "hypothetical", as was $10 \%$ of the total detected membrane proteome, validating the gene annotation process, and highlighting the possible contribution of proteins of unknown function to the biology of $H$. mustelae. Of the 26 predicted outer membrane protein in $H$. mustelae, only 4 of these, HMU0564, HMU0565, HMU1360 and HMU1367, were detected in the membrane proteome (Table 4). The fact that two of these are encoded by contiguous genes and likely cotranscribed is suggestive that their successful detection is due to similarly high expression levels. It is likely that some or many of the other predicted outer membrane proteins are actually expressed, but are below the detection limit, estimated to be in the micromolar range. Surface proteins detected in the expressed proteome also included HMU04120, a putative OM component of an efflux system. Of the 10 autotransporter proteins annotated, 7 of these were detected, at relatively high levels. Interestingly, at $1.37 \mathrm{Mol} \%$, the dominant surface ringforming protein Hsr was not the most highly expressed protein. HMU0118 was detected at $1.72 \% \mathrm{Mol} \%$ and HMU0063 at $1.73 \%$. HMU0118 is $29 \%$ identical to the Hsr protein and HMU0063 is $38.8 \%$ identical to Hsr, but in both cases, the identity at the amino terminal exposed part of the molecule is low. Although the Hsr gene was identified and cloned by immunoreactivity with antiserum raised against purified Hsr protein, and 
Table 5 The cytosolic proteome of $\boldsymbol{H}$. mustelae determined by LC-MS

\begin{tabular}{|c|c|c|c|c|c|c|c|}
\hline $\operatorname{Rank}^{a}$ & Locus & Annotation & $\begin{array}{c}\mathrm{Mw} \\
\mathrm{Da}\end{array}$ & $\begin{array}{l}\text { MOWSE } \\
\text { Score }^{\mathrm{b}}\end{array}$ & $\begin{array}{c}\text { Coverage }^{c} \\
\%\end{array}$ & emPAl $^{d}$ & $\begin{array}{c}\text { Mol } \\
\%\end{array}$ \\
\hline 1 & HMU14210 & fldA flavodoxin 1 & 18,147 & 620 & 56 & 6.74 & 7.35 \\
\hline 2 & HMU05200 & $\begin{array}{c}\text { thiJ 4-methyl-5(beta-hydroxyethyl)-thiazole monophosphate synthesis } \\
\text { protein }\end{array}$ & 20,365 & 212 & 32 & 3.64 & 3.97 \\
\hline 3 & HMU01210 & tpx probable thiol peroxidase & 17,993 & 886 & 62 & 3.43 & 3.75 \\
\hline 4 & HMU12840 & aroQ 3-dehydroquinate dehydratase & 17,477 & 161 & 21 & 2.98 & 3.25 \\
\hline 5 & HMU12860 & sodB superoxide dismutase (Fe) & 24,576 & 534 & 45 & 2.41 & 2.63 \\
\hline 6 & HMU00320 & undefined product & 8,942 & 162 & 54 & 2.16 & 2.36 \\
\hline 7 & HMU05470 & acpP acyl carrier protein & 8,469 & 139 & 48 & 2.16 & 2.36 \\
\hline 8 & HMU03120 & tuf elongation factor TU & 43,570 & 1695 & 62 & 2.09 & 2.28 \\
\hline 9 & HMU12690 & possible bacterioferritin & 17,198 & 562 & 46 & 1.99 & 2.17 \\
\hline 10 & HMU09770 & trxA thioredoxin & 11,553 & 361 & 36 & 1.89 & 2.06 \\
\hline 11 & HMU04180 & hypothetical protein Cj1613c & 30,321 & 755 & 29 & 1.71 & 1.87 \\
\hline 12 & HMU03320 & ahpC alkyl hydroperoxide reductase & 22,088 & 572 & 44 & 1.68 & 1.83 \\
\hline 13 & HMU14370 & cft ferritin & 19,056 & 276 & 45 & 1.42 & 1.55 \\
\hline 14 & HMU00950 & rpsA 30 S ribosomal protein S1 & 60,196 & 208 & 7 & 1.31 & 1.43 \\
\hline 15 & HMU10800 & IpsJ succinyl-CoA:3-ketoacid-coenzyme A transferase subunit B & 23,051 & 501 & 38 & 1.15 & 1.26 \\
\hline 16 & HMU04000 & groEL 60 kD chaperonin (cpn60) & 57,443 & 1474 & 48 & 1.02 & 1.11 \\
\hline 17 & HMU03150 & rplK 50 S ribosomal protein L11 & 12,586 & 473 & 48 & 0.90 & 0.99 \\
\hline 18 & HMU01260 & ald alanine dehydrogenase & 39,844 & 662 & 32 & 0.82 & 0.9 \\
\hline 19 & HMU07380 & hupB DNA-binding protein HU homolog & 10,122 & 352 & 56 & 0.81 & 0.89 \\
\hline 20 & HMU10120 & peb4[1]f2 major antigenic peptide PEB3II binding factor 2 & 31,816 & 750 & 39 & 0.77 & 0.85 \\
\hline 21 & HMU07050 & rpll $50 S$ ribosomal protein L9 & 16,251 & 460 & 49 & 0.74 & 0.81 \\
\hline 22 & HMU04730 & oorB OORB subunit of 2-oxoglutarate:acceptor oxidoreductase & 30,613 & 423 & 28 & 0.74 & 0.81 \\
\hline 23 & HMU14090 & putative thioredoxin & 11,796 & 267 & 39 & 0.730 & 0.8 \\
\hline 24 & HMU04740 & oorA OORA subunit of 2-oxoglutarate:acceptor oxidoreductase & 40,773 & 554 & 36 & 0.70 & 0.77 \\
\hline 25 & HMU02170 & cheY chemotaxis regulatory protein & 13,894 & 208 & 25 & 0.70 & 0.76 \\
\hline 26 & HMU11060 & putative putative aminotransferase (nifS protein homolog) & 43,365 & 424 & 26 & 0.66 & 0.73 \\
\hline 27 & HMU00290 & fbp putative putative fructose-1,6-bisphosphatase & 30,550 & 323 & 20 & 0.66 & 0.73 \\
\hline 28 & HMU03180 & rplL 50 S ribosomal protein L7/L12 & 12,946 & 259 & 44 & 0.66 & 0.73 \\
\hline 29 & HMU00100 & putative putative acyl-CoA thioester hydrolase & 16,960 & 168 & 20 & 0.63 & 0.7 \\
\hline 30 & HMU13330 & undefined product & 8,555 & 166 & 49 & 0.63 & 0.7 \\
\hline 31 & HMU03850 & flaG possible flagellar protein & 14,814 & 452 & 34 & 0.62 & 0.69 \\
\hline 32 & HMU03060 & ureB urease alpha subunit & 61,146 & 743 & 26 & 0.62 & 0.68 \\
\hline 33 & HMU09760 & $\operatorname{trxB}$ thioredoxin reductase & 33,972 & 587 & 35 & 0.62 & 0.68 \\
\hline 34 & HMU07390 & ndk nucleoside diphosphate kinase & 15,293 & 291 & 25 & 0.61 & 0.67 \\
\hline 35 & HMU05040 & putative hydantoin utilization protein B & 83,272 & 948 & 28 & 0.60 & 0.66 \\
\hline 36 & HMU10790 & scoA succinyl-CoA:3-ketoacid-coenzyme A transferase subunit A & 25,076 & 305 & 32 & 0.58 & 0.64 \\
\hline 37 & HMU03990 & groES 10 kD chaperonin (cpn10) & 10,185 & 129 & 34 & 0.58 & 0.64 \\
\hline 38 & HMU13450 & hypothetical protein Cj0706 & 27,047 & 694 & 49 & 0.55 & 0.61 \\
\hline 39 & HMU10960 & katA catalase & 52,490 & 781 & 39 & 0.53 & 0.59 \\
\hline 40 & HMU03670 & aspA aspartate ammonia-lyase & 51,394 & 620 & 31 & 0.51 & 0.57 \\
\hline 41 & HMU10290 & rpoA DNA-directed RNA polymerase alpha chain & 37,551 & 308 & 25 & 0.50 & 0.55 \\
\hline 42 & HMU11440 & putative putative nucleotide phosphoribosyltransferase & 17,378 & 164 & 25 & 0.50 & 0.55 \\
\hline 43 & HMU10630 & putative putative periplasmic protein & 21,100 & 282 & 24 & 0.48 & 0.53 \\
\hline 44 & HMU05030 & putative putative hydantoinase $\mathrm{A}$ & 78,444 & 681 & 24 & 0.47 & 0.52 \\
\hline 45 & HMU11200 & glyA serine hydroxymethyltransferase & 45,885 & 461 & 24 & 0.48 & 0.52 \\
\hline 46 & HMU08860 & hypB hydrogenase isoenzymes formation protein & 26,838 & 328 & 28 & 0.46 & 0.51 \\
\hline
\end{tabular}


Table 5: The cytosolic proteome of $\boldsymbol{H}$. mustelae determined by LC-MS (Continued)

\begin{tabular}{|c|c|c|c|c|c|c|c|}
\hline 47 & HMU01430 & putative putative periplasmic cytochrome $\mathrm{C}$ & 10,944 & 178 & 36 & 0.46 & 0.51 \\
\hline 48 & HMU06880 & yabJ putative putative regulatory protein & 13,506 & 163 & 26 & 0.46 & 0.51 \\
\hline 49 & HMU09820 & surE SurE protein homolog & 28,918 & 352 & 25 & 0.44 & 0.49 \\
\hline 50 & HMU12070 & putative putative exported protein & 16,551 & 270 & 33 & 0.44 & 0.49 \\
\hline
\end{tabular}

The 50 most abundant proteins are tabulated.

a. Relative abundance ranked by mol\%

b. Score for the entire protein derived by MASCOT, and made up of the individual scores given to each peptide sequence

c. Proportion of each protein sequence identified

d. Exponentially modified protein abundance index. See Methods for details and reference.

Table 6 Comparison of highly expressed proteins in the two dimensional electrophoresis pattern of $\boldsymbol{H}$. pylori with abundant cytosolic proteins of $\boldsymbol{H}$. mustelae detected by LC-MS

\begin{tabular}{|c|c|c|c|c|}
\hline H. pylori ORF & Protein & Annotation $^{a}$ & H. mustelae ortholog & Rank in H. mustelae proteome ${ }^{b}$ \\
\hline HP0010 & GroEL & Chaperone/heat-shock protein & HMU0400 & 16 \\
\hline HP0072 & UreB & Urease $\beta$-subunit & HMU0305 & 66 \\
\hline HP1563 & AhpC & Alkyl hydroperoxide reductase & HMU0332 & 12 \\
\hline HP0547 & Cag26 & Cag pathogenicity island protein & - & \\
\hline HP0073 & UreA & Urease $\alpha$-subunit & HMU0306 & 32 \\
\hline HP1294 & Rps4 & Ribosomal proteinS4 & HMU1030 & 120 \\
\hline HP1496 & Ctc & S4 general stress protein & HMU0808 & 193 \\
\hline HP1199 & Rpl7 & Ribosomal protein L7 & HMU0318 & 28 \\
\hline HP0390 & TagD & Adhesin-thiol peroxidase & HMU0390 & 3 \\
\hline HP0011 & GroES & Co-chaperone & HMU0399 & 37 \\
\hline HP0243 & NapA & Neutrophil activating protein & HMU1269 & 9 \\
\hline HP1286 & - & Conserved hypo. secreted protein & HMU0209 & 78 \\
\hline HP0570 & PepA & Aminopeptidase A & HMU652 & 167 \\
\hline HP1205 & TufB & Elongation factor EF-Tu & HMU0312 & 8 \\
\hline
\end{tabular}

a. H. pylori annotation; b. Cytosolic fraction

this antiserum labeled the surface rings by immunoelectron microscopy [42], the possibility remains that the surface rings are composed of more than one autotransporter protein. This would contribute to even greater antigenic variability of the $H$. mustelae surface caused by recombination of sequences for new epitopes into the expressed Hsr protein [44].

\section{Sequence motifs associated with high-level protein production}

Relative protein production levels determined by high-throughput LC-MS will be modulated by factors including transcription rates, translation efficiency, susceptibility to proteolysis, and limitations of solubility. Notwithstanding these complexities, we searched the intergenic regions of the $H$. mustelae genome for motifs associated with the genes for the 426 proteins detected in the combined proteome fractions. Only non-coding intergenic regions, from positions -40 to -200 from the start codon were searched, as most DNA-binding motifs are found within these regions [93]. This analysis identified several sequence elements strongly associated with elevated protein detection proportions. The top five variants of each of five motifs detected upstream of genes in the envelope and cytosol fraction proteomes are presented in Additional file 8 and Additional file 9. Motifs associated with the most highly expressed proteins in the membrane fraction (Motifs 1 and 2) tended to be localized 60-150 nt from the start of the ORF and might represent a binding site for a positive regulator. Motif 3 overlapped the presumptive ribosome binding site except in one case. None of the motifs appeared to correspond to a composite promoter configuration, and in the case of genes with known promoters (e.g. flaB; HMU07150), the expected $\sigma^{54}$-dependent promoter was not found. Interestingly, the motif listed in Additional file 8, Table S8 for HMU01180 was found, in identical sequence and position, on the opposite strand upstream of HMU01190. These two genes are essentially identical in the regions encoding the signal sequences and autotransporter domains, and could arguably have evolved by a gene duplication event, that would have conserved this motif without selection. Alternatively it could represent a conserved control element for these highly expressed proteins. The motifs located in the upstream flanks of the genes for highly expressed soluble proteins 
are also located further from the ORF, in most cases, than would be expected for a promoter. Motif 4, as for Motif 3 for the membrane proteins, is the Shine-Dalgarno sequence. Genome-wide functional analysis of helicobacter expression signals, by transcript mapping, deletion analyses and gene fusions, is warranted.

\section{Comparative Genomics and phylogeny of the $\varepsilon$-Proteobacteria}

Alignment of the $H$. mustelae genome sequence with those of $W$. succinogenes, C. jejuni, H. pylori and $H$. hepaticus revealed lack of extensive i.e. long-range synteny with any of these genomes (Fig. 5), a feature noted for other genomic comparisons within the Campylobacterales [35]. Although the ACT software allows

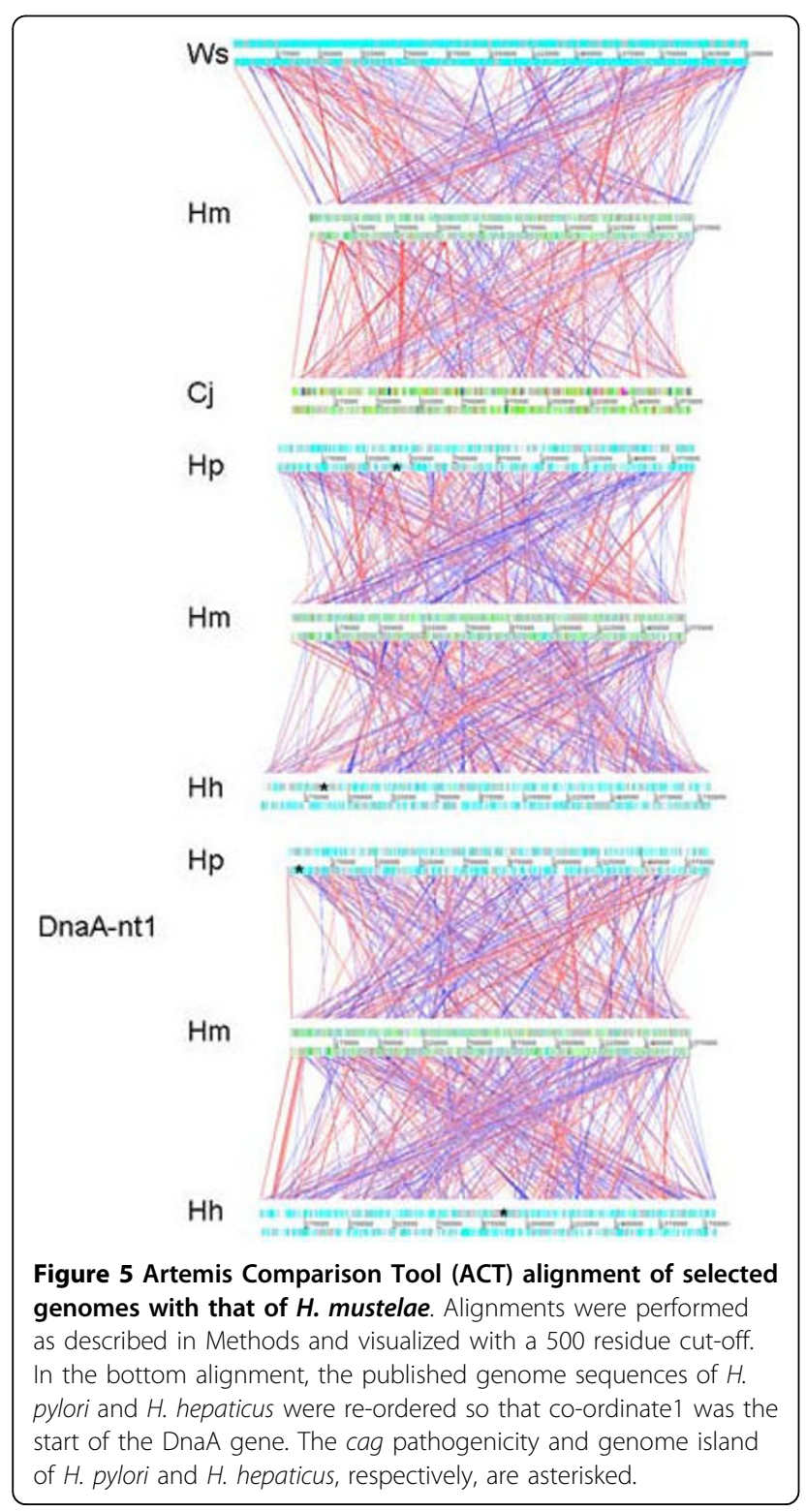

visualization of mutually reversed homologous sequences, it was noteworthy that comparing $H$. mustelae to $W$. succinogenes or C. jejuni seemed to more clearly highlight a vestigial genome backbone than comparing it to H. pylori or H. hepaticus (Fig. 5). Re-orienting the $H$. pylori and $H$. hepaticus genomes with the $d n a A$ genes at co-ordinate 1 partly clarified the rungs of a conserved ladder of homology between the genomes, but this was still largely obscured by the numbers of relative transpositions and reversions of multiple loci between the genomes. The rungs in the ladder are formed by genes including $\operatorname{dna} A$, gyrase, a putative metallo-beta-lactamase (shared with $H$. hepaticus), and gatB, the 2-oxoglutarate:acceptor oxidoreductase operon. This analysis also highlighted the degree to which lack of synteny in the compared genomes is due to transposition across the origin-terminus axis, resulting in an $\mathrm{X}$-shaped alignment that is symmetric about the origin of replication as previously noted in other bacteria by Eisen [94]. This symmetry indicates homologous loci at the same distance from the origin but on the opposite side of the origin, which is explained by the fork replication theory [95]. The genome alignments highlight the absence of the $H$. pylori cag pathogenicity island and the $H$. hepaticus genomic island (from $\mathrm{HH} \_232$ to $\mathrm{HH} \_303$ ) in the $H$. mustelae genome (Fig. 5). Relatively few longer stretches of the $H$. mustelae genome lack any significant homologues in $H$. pylori or $H$. hepaticus; those that exist include HMU00600-HMU00690 that includes AT cluster 1; HMU01180-HMU01200 including AT cluster 2; and HMU10860-HMU10880 that encodes a predicted tricarboxylate transport system not found in the other Helicobacter species.

To explore the phylogenomics of the Campylobacterales for which genome sequence data were available, we first performed pair-wise alignments of their proteomes and then constructed a matrix based on their relatedness. Using methods derived during our studies of another bacterial group within which genetic distances are very long, the Lactobacillales [96], we defined orthologues at protein level, requiring 30\% identity over $80 \%$ of the sequence lengths. The pair-wise alignment data is presented in Additional file 10. These data indicated that $H$. mustelae was closest phylogenetically to $H$. hepaticus, followed by $H$. pylori and the the Campylobacters. A tree constructed based on 212 orthologous proteins shared between the respective taxa (Fig. 6) showed two major branches, one including the four Camplyobacter genomes. In the second branch, $H$. mustelae clustered most closely with $H$. pylori and with the enterohepatic species $H$. hepaticus. W. succinogenes was peripheral to the Campylobacter clade. This topology is more concordant with the $16 \mathrm{~S}$ rRNA phylogeny of Dewhirst [26] and Gueneau [25] than with the 23S 


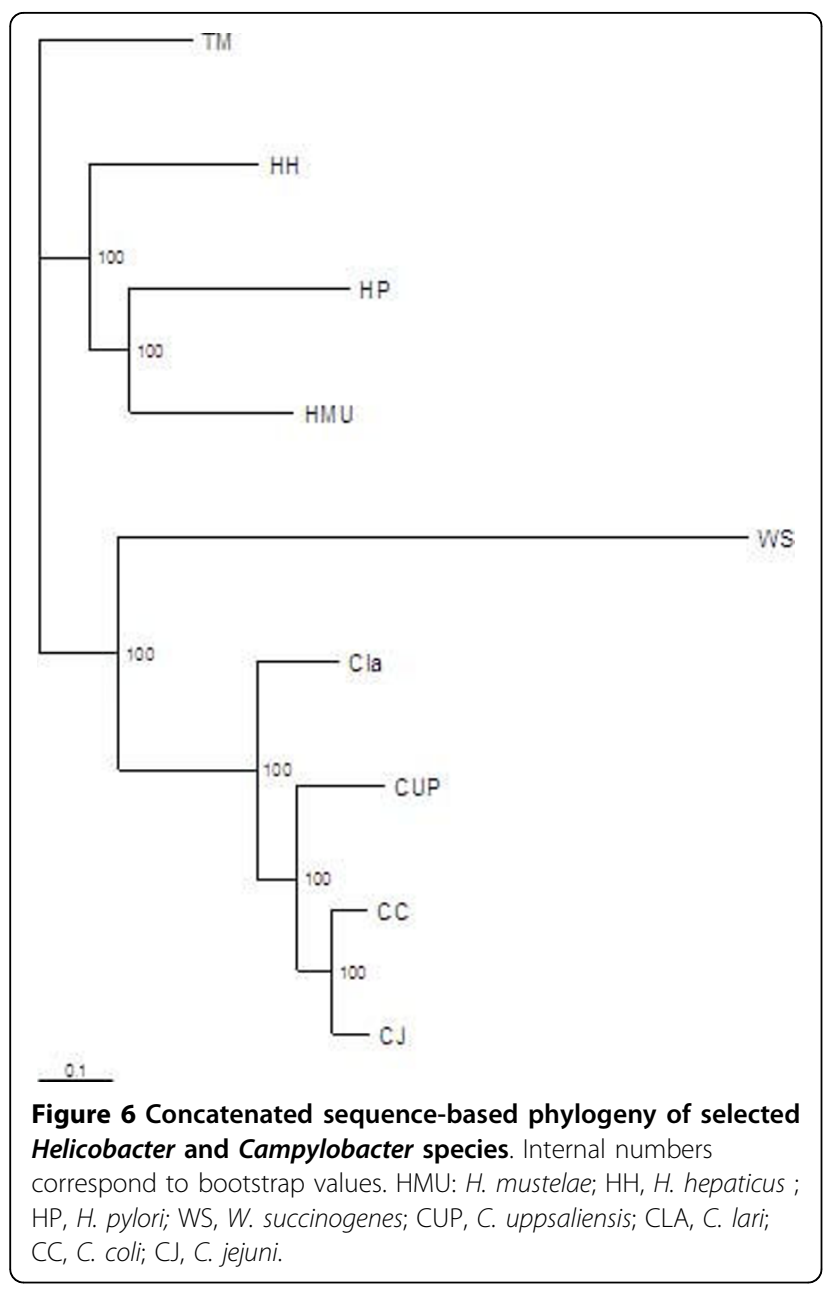

rRNA gene phylogeny constructed by Dewhirst et al, which the authors suggested to be more robust [26]. The positioning of W. succinogenes in particular by the 23S rRNA gene phylogeny is significantly different from that based on numbers of orthologs in the current study including $H$. mustelae. Our exclusion of W. succinogenes from the helicobacters also conflicts with a phylogeny constructed in the same study by Dewhirst and colleagues [26], based on 870 shared proteins.

We have previously used Supertree analysis to clarify relatedness in distant taxa [96]. The advantage of this approach is that it combines the maximum likelihood trees constructed from each of hundreds of core proteins, in this case the 212 proteins shared by all taxa (Fig. 7). This all-against-all comparison identified numbers of proteins specific to major groups (Fig. 7). The three helicobacters constituted a reasonably robust group, with over thirteen hundred core proteins, compared to 1097 in the four campylobacters. The consensus supertree constructed for the eight Campylobacterales plus outgroup is presented in Fig. 8. Based on this more restricted set of core proteins, W. succinogenes still positioned on the edge of the Helicobacter clade. $H$. pylori was most closely related to $H$. mustelae. However this H. pylori-H. mustelae branch was the least supported by the combined frequencies of the individual maximum likelihood trees, indicating the instability of this phylogenetic relationship. Considering the pairwise comparisons, whereby $H$. mustelae was most closely related to $H$. hepaticus (Additional file 9, Table S9), the choice of proteins clearly has a profound affect on the

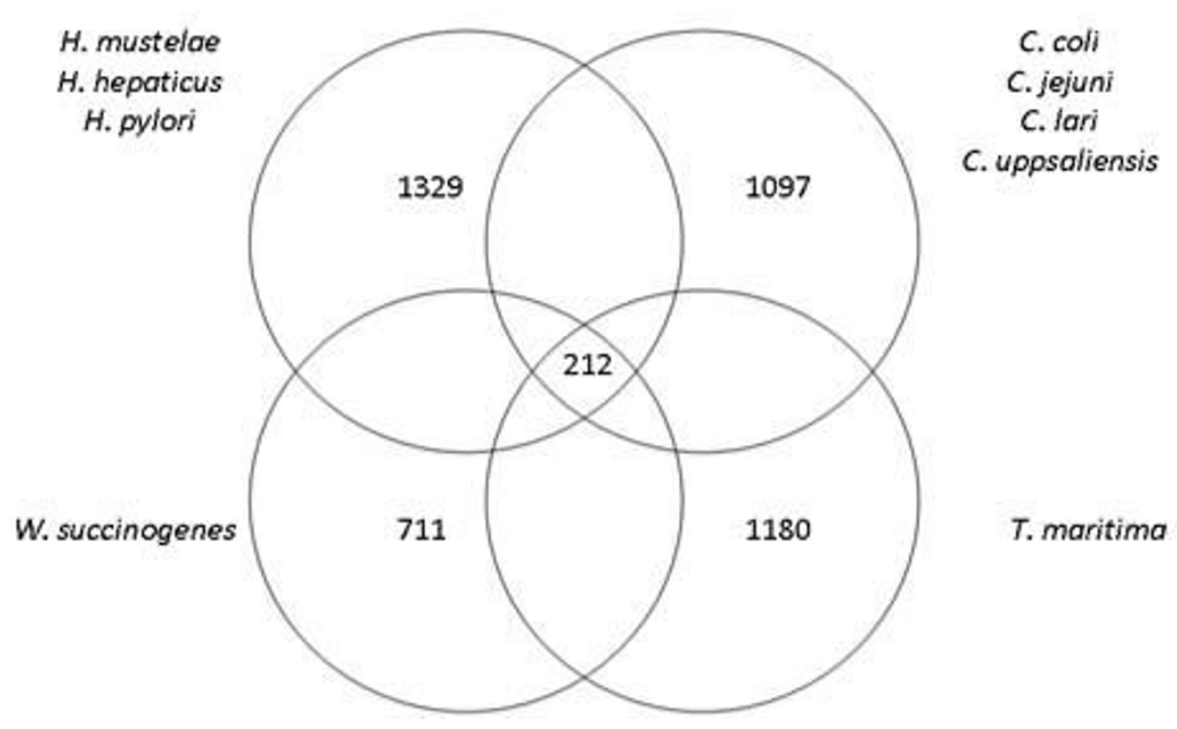

Figure 7 Venn diagram showing numbers of orthologous proteins for genera within selected Campylobacterales whose genome sequences were analyzed. 


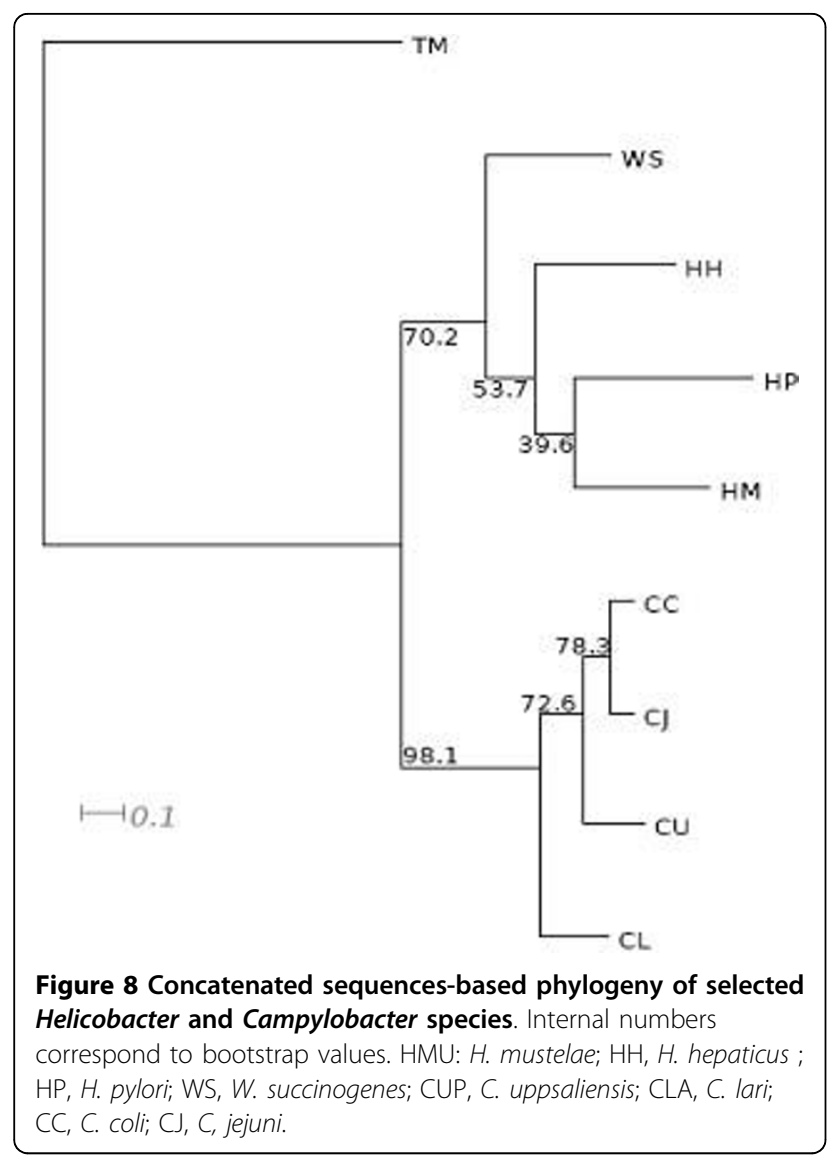

phylogeny inferred. The choice of T. maritima as outgroup may also have affected the outcome, but the number of shared orthologs was only 252 when this taxon was not included in the all-against-all comparison, suggesting this was not a major factor. As for the pairwise ortholog analysis and the phylogeny based on concatened core proteins (Fig. 6), W. succinogenes did not cluster among the helicobacters, and the data do not support the notion of revising the nomenclature of these genera [26].

\section{Conclusions}

H. pylori infects over half the global population [97]. Although the majority of infected individuals do not develop cancer [98], the prevalence rates mean that a significant number of subjects will suffer a preventable neoplastic transformation. Development of mammalian cancer in response to bacterial infection is a relatively recently recognized phenomenon [99], and this outcome has also been robustly attributed to $H$. hepaticus and $H$. mustelae. The H. mustelae-ferret system presents a model for studying the development of gastric cancer. Chronic inflammation is a risk factor for cancer, because of a shift in the balance of pro- and anti-apoptotic genes towards a more anti-apoptotic phenotype [100]. Human infections with cag-positive strains of $H$. pylori are much more frequently associated with neoplastic outcomes [101]. Cag-minus strains are less infrequently associated with non-atrophic gastritis and duodenal ulceration [102]. However it has long been recognized that infection with Cag-minus $H$. pylori poses a significantly greater risk for gastric cancer compared to non-infection [103]. Indeed in a recent primary study and accompanying meta-analysis, the increased gastric cancer risk due to infection by a Cag-minus strain compared to noninfection was four-fold [104], and the reviewed values in well controlled studies ranged from two-fold to fivefold. Given the time-scale over which neoplastic transformations occur, the development of cancer due to Helicobacter spp. will likely have a major component of chronic inflammation. Among the three species known to be carcinogenic, convergent infection-related disturbances of pro-apoptotic pathways is thus likely to be the key feature, rather than a single pro-carcinogenic microbial product or metabolite common to all three species. The strong linkage of cag to human gastric cancer thus appears to be a specific host-bacterium phenomenon. A search for "carcinogenicity determinants" should encompass complex persistence mechanisms and host-interaction molecules, and not focus solely on overt effectors such as CagA. Animal model systems may be useful for such searches. Haas and colleagues identified 47 $H$. pylori genes that were required for gastric colonization of the Mongolian Gerbil [105]. Orthologues of all but three of these genes are found in the H. mustelae genome (Additional file 11), including a collagenase shown to be a functional enzyme when cloned from $H$. pylori [105]. Some of the H. mustelae orthologues are quite divergent, suggesting a degree of host-adaptation or lack of strong selection, but nevertheless indicating that the primary gastric persistence mechanisms of H. pylori and H. mustelae are essentially conserved.

In addition to the lack of cag in $H$. mustelae, the lack of VacA and the major H. pylori adhesins indicates that colonization and persistence of these two gastric species is mechanistically different. This may simply reflect immunological and physiological differences between ferret and human stomach [106], but also the fact that the pathology of human gastritis is generally more severe [13]. The striking abundance of autotransporter proteins in $H$. mustelae strongly indicates a role for these molecules in host interaction. The Hsr AT protein decorates the $H$. mustelae surface in a paracrystalline array of ring structures that are antigenically variable, presumably to avoid a humoral immune response that would clear the infection. Attempts to develop vaccines against $H$. pylori have been largely unsuccessful, despite promising animal trials (reviewed in ref. [107]). The reasons for this failure are complex, but include the fact 
that key adhesins are low copy number OMPs, and that immune cells are actively targetted by VacA. Investigation of how the ferret immune response may be exploited to eradicate or prevent $H$. mustelae infection could be informative for preventing $H$. pylori infection in humans.

Paradoxically, C. jejuni persists as a commensal of birds, and W. succinogenes as a commensal of ruminants, despite both genomes being endowed with known (C. jejuni) or inferred (W. succinogenes) virulence determinants. As the sequencing of its genome has revealed, some of these are also shared with $H$. mustelae. Just as has been argued for H. pylori strains [2], and for pathogens in general [108], what defines a pathogen and a disease outcome involves the phenotype of the microbe, the genotype of the host, and the vigour and appropriateness of the host response. Comparative and functional genomics of the $\varepsilon$-proteobacteria will be a fertile area to explore these hypotheses.

\section{Methods}

\section{Cell culture and growth conditions}

Helicobacter mustelae strain 12198 (identical to CCUG 25175 and ATCC 43772, the type strain of H. mustelae) was cultured as described previously $[87,109]$ on chocolate blood agar plates (CBA; Oxoid Basingstoke, Hampshire, UK) for $48 \mathrm{~h}$ at $37^{\circ} \mathrm{C}$ in an atmosphere containing $5 \% \mathrm{CO}_{2}$.

\section{DNA extraction, genome sequencing, and annotation}

High molecular weight genomic DNA of $H$. mustelae was extracted as previously described [42]. The genome of $H$. mustelae strain 12198 was sequenced to approximately 8-fold coverage, from pUC18 (insert size 2.8-3.3 $\mathrm{kb}$ and 3.0-3.3 kb) genomic shotgun libraries using bigdye terminator chemistry on ABI3730 automated sequencers. End sequences from large insert BAC libraries in pBACehr (insert size 10-25 kb) and pBACe3.6 (insert size 12-15 kb) were used as a scaffold. All repeat regions were bridged by read-pairs or endsequenced polymerase chain reaction (PCR) products. The sequence was finished to standard criteria [110]. Sequence assembly, visualization, and finishing were performed using PHRAP (http://www.phrap.org; P. Green, unpublished data) and Gap4 [111]. The sequence and annotation of the H. mustelae 12198 genome has been deposited in EMBL/GenBank/DDBJ under accession number FN555004.

The $H$. mustelae genome sequence was annotated using Artemis software [112]. Initial coding sequence (CDS) predictions were determined by Orpheus [113], Glimmer2 [114], and EasyGene software [115]. These predictions were collated and combined, and were further refined by reference to codon usage, positional base preference methods and comparisons to the non redundant protein databases using BLAST [116] and FASTA [117]. The entire DNA sequence was also compared in all six potential reading frames against UniProt, using BLASTX [116] to identify any possible coding sequences previously missed. Protein motifs were identified using Pfam [118] and Prosite [119], transmembrane domains were identified with TMHMM [120], and signal sequences were identified with SignalP version 2.0 [121]. rRNAs were identified using BLASTN [116] alignment to defined rRNAs from the EMBL nucleotide database; tRNAs were identified using tRNAscan-SE [122]; stable RNAs were identified using Rfam [123].

The $H$. mustelae genome was visualized in circular format using Genomeviz [124]. The input MAP file was produced from the corresponding Artemis file. COGS were assigned on the basis of a BLASTP comparison to an in-house COG database. GC \% and GC skew maps were also generated in Genomeviz, with a window size of $1000 \mathrm{bp}$, and an overlap of $500 \mathrm{bp}$ between windows.

Regions of the genome likely acquired by horizontal gene transfer were identified using the Alien Hunter algorithm [125] which works by finding local compositional biases based on a variable-order motif distributions method [125].

Motif searches, for detecting conserved motifs upstream of highly expressed genes, were performed using MEME [126], searching positions -40 to -200 of start codons. If the intergenic region was less that $40 \mathrm{nt}$, the downstream ORF in question was considered to be part of a operon and the intergenic region upstream of the first gene in the operon was selected for analysis. MEME was instructed to search the given strand (coding strand) for motifs between 6 and $50 \mathrm{bp}$ in length and only on the coding strand. The MEME statistical parameter zoops (Zero or one Occurrence per Sequence) was set in the run command. Only motifs with an $E$ value of $<0.001$ were considered relevant [126]. Weblogos summarizing the consensus motifs were derived using MEME. The E-value of a motif was defined as the number of motifs as good as or better than the motif in question which would appear in a random set of sequences the same size as the training set. The P-value is the probability that a random string will have the same score as the current one, and is thus an indication of the degree of similarity a string has to the consensus.

\section{Comparative genomics}

Outer membrane protein phylogeny was investigated by first aligning a combined dataset of H. pylori 26695 and H. mustelae predicted OMPs in MUSCLE [127], using the phylogeny.fr web server [128]. The aligned sequences were then used to construct a maximum 
likelihood phylogeny with Phyml [129]. Branch support values were calculated using the Approximate Likelihood Ratio test or aLRT) [130].

Sequence data for the in silico analyses were obtained from the NCBI reference sequences (RefSeq) for the circularized genomes of Helicobacter hepaticus ATCC 51449 (NC_004917), H. pylori 26695 (NC_000915), Campylobacter jejuni subsp. jejuni NCTC 11168 (NC_002163), Wolinella succinogenes DSM 1740 (NC_005090) and Thermotoga maritima MSB8 (NC_000853) and for the incomplete genome sequences of C. upsaliensis RM3195 (AAFJ01000001), C. lari RM2100 (NC_012039) and C. coli RM2228 (AFL01000001). Proteome sets consisted of the translated gene sequences of respective complete or incomplete genomes.

Whole genomes were aligned using the Artemis Comparison Tool (ACT) [131]. Full genome sequence comparisons were performed using the BLAST program bl2seq. Comparisons were done at protein level with an e-value cut-off of 1E-08. Blast results were parsed with MSPcrunch and the resulting files visualized with ACT. In order to improve the visualization of synteny in the graphical alignments, the start regions of the $H$. pylori and $H$. hepaticus genome sequences were shifted to the beginning of their corresponding $d n a A$ genes.

Proteome sets derived from respective complete or incomplete annotated bacterial genomes were compared pairwise, and all-against-all using BLASTP [116]. Our working definition of orthology was protein sequences that reciprocally shared more than $30 \%$ sequence identity using BLASTP over at least $80 \%$ of total sequence length, so that sets of pair-wise and all-against-all orthologs were obtained, correspondingly. The former set was used to build a pairwise comparison matrix, where the lower triangle indicates the total number of orthologs in genome-genome comparisons while the upper triangle shows the average sequence identity values expressed in percentage.

For the consensus tree, each of the 212 protein sequences were aligned using ClustalW, their best protein model of evolution was chosen, and a maximum likelihood tree was built for each protein set using Multiphyl [132]. Using these trees, a final consensus tree was built using the option ConsensusNetwork with a threshold of 0.33 using the Edge Weights mean option. To construct the concatenated phylogenomic tree, the 212amino acid sequences were concatenated for each organism. The resulting final sequences were aligned using Mafft v6.240 [133] with the option "auto". Columns in the resulting alignment with gaps in more than $50 \%$ of the sequences were deleted using Gblocks [134] in order to avoid poorly aligned positions and divergent regions. Using these sequences, a maximum likelihood tree was built using Phyml 3.0 [129] with default values and a bootstrap of 100 replicates. The resulting tree was visualized using TreeView [135], and in both consensus and concatenated trees T. maritima was used as an outgroup.

\section{Protein extraction and quantification}

All reagents were purchased from Sigma-Aldrich (Poole, UK) with the exception of mass spectrometry grade water and acetonitrile, which were purchased from Romil (Cambridge, UK) and trypsin, which was purchased from Promega (Southampton, UK).

Bacterial cells were harvested from CBA plates into phosphate buffered saline pH 7.4 (PBS; Sigma, Dorset, UK) and cell numbers were adjusted by the addition of PBS to obtain absorbance values of $0.5(600 \mathrm{~nm})$, determined by viable count to be equivalent to $4 \times 10^{8} \mathrm{CFU}$ $\mathrm{ml}^{-1}$. A $20 \mathrm{ml}$ volume of each cell suspension was centrifuged at $8,600 \times \mathrm{g}$ at $4^{\circ} \mathrm{C}$ for $30 \mathrm{~min}$. Cell pellets were weighed and resuspended in $10 \mathrm{mM}$ PBS (pH 7.8) at ratios of $1 \mathrm{~g}$ cells to $2 \mathrm{ml}$ buffer. The cells were then broken using sonication as described previously by Graham et al. [136]. The soluble proteome fraction was isolated by centrifugation of the homogenate at $25,000 \times \mathrm{g}$ for $30 \mathrm{~min}$ at $3-5^{\circ} \mathrm{C}$ (Beckman J2-HS, Beckman Instruments, CA, USA) followed by ultracentrifugation at $150,000 \times \mathrm{g}$ for 2 hours at $3-5^{\circ} \mathrm{C}$ (Beckman L8-M, Beckman Instruments, CA, USA) to sediment insoluble fractions. Supernatant fractions were decanted and stored in $1 \mathrm{ml}$ aliquots at $-70^{\circ} \mathrm{C}$ until required. The insoluble fractions were weighed and resuspended in 2\% SDS in PBS at ratios of $1 \mathrm{~g}$ cells to $2 \mathrm{ml}$ buffer, treated in for 45 mins at $4^{\circ} \mathrm{C}$, and then also stored in $100 \mu \mathrm{l}$ aliquots at $-70^{\circ} \mathrm{C}$ until required.

\section{One Dimensional Gel Electrophoresis}

Protein concentrations were measured using the Bradford assay [137] and aliquots of supernatant and insoluble fractions were added to $10 \mu \mathrm{L}$ Tris-Glycine SDS sample loading buffer (Invitrogen, Renfrewshire, UK), made up to $40 \mu \mathrm{l}$ with $\mathrm{dH} 2 \mathrm{O}$, and boiled for $5 \mathrm{~min}$. The samples $(20 \mu \mathrm{L} ; 100 \mu \mathrm{g}$ total protein) were loaded onto a $1 \mathrm{~mm}$ thick Nu-Page 4-12\% Bis-Tris gel (Invitrogen, Renfrewshire, UK). SeeBlue ${ }^{\mathrm{mm}}$ Plus 2 (Invitrogen, Renfrewshire, UK) was used as a protein molecular mass marker. The gel was electrophoresed, using MES SDS running buffer, in an X-Cell II mini gel system (Invitrogen, Renfrewshire, UK) at $200 \mathrm{~V}, 120 \mathrm{~mA}, 25 \mathrm{~W}$ per gel for $35 \mathrm{~min}$. Proteins were visualised using SimplyBlue $^{\text {ta }}$ Safestain (Invitrogen, Renfrewshire, UK). The entire lane was excised from the gel and cut into eight fractions based on molecular mass as previously described by Graham et al. $[138,139]$ 


\section{In-Gel Tryptic Digestion}

Excised gel fractions were washed for $30 \mathrm{~min}$ in 200 $\mathrm{mM} \mathrm{NH} \mathrm{NHCO}_{3}, \mathrm{pH} 7.8$ at $37^{\circ} \mathrm{C}$. These fractions were then dehydrated by incubation for $30 \mathrm{~min}$ in $200 \mathrm{mM}$ $\mathrm{NH}_{4} \mathrm{HCO}_{3} \mathrm{pH} 7.8 / \mathrm{MeCN}(4: 6 \mathrm{v} / \mathrm{v})$ at $37^{\circ} \mathrm{C}$, followed by rehydration for $30 \mathrm{~min}$ in $50 \mathrm{mM} \mathrm{NH}_{4} \mathrm{HCO}_{3}$, $\mathrm{pH} 7.8$ at $37^{\circ} \mathrm{C}$. Following incubation in $100 \%$ acetonitrile for 2 min, $0.1 \mu \mathrm{g}$ trypsin in $50 \mathrm{mM} \mathrm{NH} \mathrm{HCO}_{3}, \mathrm{pH} 7.8$ was added to each sample, which was then incubated overnight at $37^{\circ} \mathrm{C}$. The supernatant was subsequently recovered into microcentrifuge tubes and a second peptide extraction from these gel pieces was carried out $(0.1 \%$ TFA in $60 \%$ acetonitrile for $5 \mathrm{~min}$ ). Peptide-containing liquid fractions were pooled, dried under vacuum and re-suspended in $20 \mu \mathrm{L} 0.1 \%$ formic acid in $2 \%$ acetonitrile prior to storage at $-70^{\circ} \mathrm{C}$ until required.

\section{Liquid Chromatography-Mass Spectrometric Analysis (LC-MS)}

Mass spectrometry was performed using a 3200 Q-TRAP Hybrid ESI Quadropole linear ion trap mass spectrometer, ESI-Q-q-Qlinear ion trap-MS/MS (Applied Biosystems/MDS SCIEX, Toronto, Canada) with a nanospray interface, coupled with an online Ultimate 3000 nanoflow liquid chromatography system (Dionex/LC Packings, Amsterdam, The Netherlands). A $\mu$-Precolumn ${ }^{\text {tw }}$ Cartridge $(300 \mu \mathrm{m} \times 5 \mathrm{~mm}, 5 \mu \mathrm{m}$ particle size) was placed prior to the $\mathrm{C}_{18}$ capillary column (75 $\mu \mathrm{m} \times 150 \mathrm{~mm}, 3 \mu \mathrm{m}$ particle size) to enable desalting and filtering. Both columns contained the reversed phase material PepMAP ${ }^{\mathrm{max}} 100\left(\mathrm{C}_{18}\right.$ silica-based $)$ with a $100 \AA ̊$ pore size (Dionex/LC Packings). The elution buffers used in the gradient were Buffer A $(0.1 \%$ formic acid in $2 \%$ acetonitrile) and Buffer B (0.1\% formic acid in $80 \%$ acetonitrile). The nanoLC gradient used was 60 min in length: $0-55 \% \mathrm{~B}$ in $45 \mathrm{~min}, 10 \mathrm{~min}$ at $90 \% \mathrm{~B}$ followed by $5 \mathrm{~min}$ at $100 \% \mathrm{~A}$. The flow rate of the gradient was $300 \mathrm{nLmin}^{-1}$. The detector mass range was set at $400-2000 \mathrm{~m} / z$. MS data acquisition was performed in positive ion mode. During MS acquisition peptides with ${ }^{2+}$ and $^{3+}$ charge state were selected for fragmentation.

\section{Database Searching, Protein Identification and PROVALT Analysis}

Protein identification was carried out using an internal MASCOT server (version 1.9; Matrix Science, London, UK) searching against the $H$. mustelae genome database. Peptide tolerance was set at $\pm 2.0 \mathrm{Da}$ with MS/MS tolerance set at $\pm 0.8 \mathrm{Da}$ and the search set to allow for 1 missed cleavage, and allowed for fixed modifications of carbamidomethylation and variable modifications of oxidation of methionine residues. In order to expedite the curation of the identified protein list from MASCOT, the result files were re-analysed against an extracted database comprising the $H$. mustelae file using the heuristic method known as the protein validation tool PROVALT [140]. This automated program takes large proteomic MS datasets and reorganises them by taking multiple MASCOT results and identifying those peptides that match. Redundant peptides are removed and related peptides are grouped together associated with their predicted matching protein, thus, the program dramatically reduces this portion of the curation process. For identification purposes the minimum peptide length was set at 6 amino acids, minimum peptide MOWSE score was set at 10 and the minimum high quality peptide MOWSE score was set at 22. PROVALT also uses peptide matches from a random database (in this case the extracted $H$. mustelae protein database was randomised) to calculate false-discovery rates (FDR) for protein identifications as previously described by Weatherley et al. [140]. Briefly, identifications from searching the normal and random databases are used to calculate the FDRs and set score thresholds and thus identify as many 'actual' proteins as possible while encountering a minimal number of false-positive protein identifications. Rather than calculate error rates at the peptide level, the FDR calculations employed by PROVALT provide a reasonable balance between the number of correct and incorrect protein assignments. In this study the FDR was set at $1 \%$, meaning that $99 \%$ of the reported proteins identified should be correct. All detected proteins were then quantified by utilising the exponentially modified protein abundance index (emPAI) $[139,141,142]$. This method allows the quantification of individual identified proteins by utilising database and MASCOT output information (based on number of peptides identified), in order to give an emPAI value http://www.matrixscience.com/help/quant_empai_help.html. The emPAI values were then be used to estimate protein content within sample mixtures in molar fraction percentages as previously described $[139,141,142]$.

\footnotetext{
Additional file 1: Autotransporter loci in the $H$. mustelae genome. Click here for file

[http://www.biomedcentral.com/content/supplementary/1471-2164-11164-S1.DOCX]

Additional file 2: Blood group antigen-associated genes in the genome sequence of $H$. mustelae, and compared with $H$. pylori Click here for file

[http://www.biomedcentral.com/content/supplementary/1471-2164-11164-S2.DOCX]

Additional file 3: Motility- and flagellum-associated genes in the genome sequence of $H$. mustelae, and compared with $H$. pylori Click here for file

[http://www.biomedcentral.com/content/supplementary/1471-2164-11164-S3.DOCX ]
} 
Additional file 4: Protein secretion-associated genes in the genome sequence of $H$. mustelae, and compared with $H$. pylori

Click here for file

[http://www.biomedcentral.com/content/supplementary/1471-2164-11164-S4.DOCX ]

Additional file 5: Presence of homopolyeric tracts within/between $H$. mustelae genes, and homopolymer length variation in sequence data

Click here for file

[http://www.biomedcentral.com/content/supplementary/1471-2164-11164-S5.DOCX ]

Additional file 6: The envelope proteome of $H$. mustelae determined by LC-MS.

Click here for file

[http://www.biomedcentral.com/content/supplementary/1471-2164-11164-S6.DOCX]

Additional file 7: The cytosolic proteome of $\mathrm{H}$. mustelae determined by LC-MS

Click here for file

[http://www.biomedcentral.com/content/supplementary/1471-2164-11164-S7.DOCX]

Additional file 8: Motifs associated with highly expressed genes in the $H$. mustelae cell envelope proteome

Click here for file

[http://www.biomedcentral.com/content/supplementary/1471-2164-11164-S8.DOCX ]

Additional file 9: Motifs associated with highly expressed genes in the H. mustelae cytosol proteome

Click here for file

[http://www.biomedcentral.com/content/supplementary/1471-2164-11164-S9.DOCX]

\section{Additional file 10: Orthologue comparisons between selected}

Campylobacterales, and T. maritima as out-group. The lower triangle indicates the total number of orthologs in genome-genome comparisons while the upper triangle shows the average sequence identity values expressed in percentages.

Click here for file

[http://www.biomedcentral.com/content/supplementary/1471-2164-11164-S10.DOCX]

Additional file 11: Presence in $H$. mustelae of orthologues of $H$. pylori genes identified as essential for colonization of the Mongolian gerbil.

Click here for file

[http://www.biomedcentral.com/content/supplementary/1471-2164-11164-S11.DOCX]

\section{Acknowledgements}

PWOT is supported by the (Govt. of Ireland) Dept. Agriculture Fisheries and Food FHRI award to the ELDERMET project, and by CSET and PI awards from Science Foundation Ireland. W.J.S. and R.L.J.G. were supported by The Northern Ireland Centre of Excellence in Functional Genomics, with funding from the European Union (EU) Program for Peace and Reconciliation, under the Technology Support for the Knowledge-Based Economy. CJ was supported by the German Ministry of Research and Education (ERAnet PathoGenomics). We thank Sebastian Suerbaum, Jim Fox and Torkel Wadström for supporting the application to the Wellcome Trust to sequence the $H$. mustelae genome; lan Goodhead, Karen Mungall and other members of the Sanger Centre genome finishing team; David Harris for homopolymer tract analysis; François Douillard for motility assays; Fang Fang and Marcus Claesson for assistance with phylogeny; and Marguerite Clyne for supplying the $H$. mustelae type strain.

\section{Author details}

${ }^{1}$ Department of Microbiology, \& Alimentary Pharmabiotic Centre, University College Cork, Cork, Ireland. ${ }^{2}$ School of Biomedical Sciences, University of Ulster, Coleraine, County Londonderry, BT52 1SA, N. Ireland, UK. ${ }^{3}$ Department of Biochemistry, Genetics and Immunology, University of Vigo, 36310 Vigo, Spain. ${ }^{4}$ School of Molecular Medical Sciences, University of Nottingham, Centre for Biomolecular Sciences, Nottingham NG7 2RH, UK. ${ }^{5}$ Hannover Medical School, Department for Medical Microbiology and Hospital Epidemiology, Hannover, Germany. ${ }^{6}$ Pathogen Genomics, Wellcome Trust Sanger Institute, Wellcome Trust Genome Campus, Hinxton, CB10 1SA, UK. ${ }^{7}$ Current Address:Cavanilles Institute of Biodiversity and Evolutionary Biology, Department of Genetics, University of Valencia, Valencia, Spain.

\section{Authors' contributions}

PWOT conceived of the study, participated in its design and coordination, analyzed the data and drafted the manuscript. WJS prepared sub-cellular fractions and analyzed them by 1DE and LC-MS. CC performed comparative genome analysis, phylogeny and phylogenomics. BMF performed genome sequence analysis. KRH and CJ annotated secretion system genes, and flagellar genes, respectively. RLG and GMcM conceived the LC-MS analysis and analyzed proteome data. EB performed gene prediction and annotation. JP and SB designed and implemented the sequencing strategy, analyzed the data and drafted the manuscript. All authors read and approved the final manuscript.

Received: 30 September 2009 Accepted: 10 March 2010

Published: 10 March 2010

\section{References}

1. Solnick JV, Vandamme P: Taxonomy of the Helicobacter genus. Helicobacter pylori: physiology and genetics Washington D.C.: ASM PressMobley HLT, Mendz GL, Hazell SL 2001, 39-51.

2. Cover $\mathrm{TL}$, Blaser MJ: Helicobacter pylori in health and disease. Gastroenterology 2009, 136:1863-1873.

3. Graham DY, Lew GM, Evans DG, Evans DJ, Klein PD: Effect of triple therapy (antibiotics plus bismuth) on duodenal ulcer healing - a randomized controlled trial. Ann Intern Med 1991, 115:266-269.

4. Veldhuyzen van Zanten SJ, Sherman PM: Helicobacter pylori infection as a cause of gastritis, duodenal ulcer, gastric cancer and nonulcer dyspepsia: a systematic overview. Can Med Assoc J 1994, 150:177-185.

5. Eurogast SG: An international association between Helicobacter pylori infection and gastric cancer. Lancet 1993, 341:1360-1362.

6. Parsonnet J, Hansen S, Rodriguez L, Gelb AB, Warnke RA, Jellum E, Orentreich N, Vogelman JH, Friedman GD: Helicobacter pylori infection and gastric lymphoma. N Engl J Med 1994, 330:1267-1271.

7. Solnick JV, Schauer DB: Emergence of diverse Helicobacter species in the pathogenesis of gastric and enterohepatic diseases. Clin Microbiol Rev 2001, 14:59-97.

8. Fox JG, Yan L, Shames B, Campbell J, Murphy JC, Li X: Persistent hepatitis and enterocolitis in germfree mice infected with Helicobacter hepaticus. Infect Immun 1996, 64:3673-3681.

9. Fox JG, Li X, Yan L, Cahill RJ, Hurley R, Lewis R, Murphy JC: Chronic proliferative hepatitis in $\mathrm{A} / \mathrm{JCr}$ mice associated with persistent Helicobacter hepaticus infection: a model of helicobacter-induced carcinogenesis. Infect Immun 1996, 64:1548-1558.

10. Cahill RJ, Foltz CJ, Fox JG, Dangler CA, Powrie F, Schauer DB: Inflammatory bowel disease: an immunity-mediated condition triggered by bacterial infection with Helicobacter hepaticus. Infect Immun 1997, 65:3126-3131.

11. Enserink M: Ferrets Shed Light on New Virus's Severity and Spread. Science 2009, 325:17.

12. Fox JG, Otto G, Murphy JC, Taylor NS, Lee A: Gastric colonization of the ferret with Helicobacter species - natural and experimental infections. Rev Inf Dis 1991, 13:S671-S680.

13. Fox JG, Correa P, Taylor NS, Lee A, Otto G, Murphy JC, Rose R: Helicobacter mustelae -associated gastritis in ferrets: an animal model of Helicobacter pylori gastritis in humans. Gastroenterology 1990, 99:352-361.

14. Fox JG, Chilvers T, Goodwin CS, Taylor NS, Edmonds P, Sly LJ, Brenner D: Campylobacter mustelae, a new species resulting from the elevation of Campylobacter pylori subsp. mustelae to species status. Int I Syst Bacteriol 1989, 39:301-303.

15. Goodwin CS, Chilvers T, Peters M, Collins D, Sly I, McConnell W: Transfer of Campylobacter pylori and Campylobacter mustelae to Helicobacter gen. nov as Helicobacter pylori comb. nov. and Helicobacter mustelae comb. nov. respectively. Int J Syst Bacteriol 1989, 39:397-405. 
16. Fox JG, Edrise BM, Cabot EB, Beaucage AC, Murphy JC, Prostak KS: Campylobacter -like organisms isolated from gastric mucosa of ferrets. Amer J of Vet Res 1986, 47:352-361.

17. Goodwin CS, Armstrong JA, Chilvers T, Peters M, Collins MD, Sly L, McConnell W, Harper WES: Transfer of Campylobacter pylori and Campylobacter mustelae to Helicobacter Gen-nov as Helicobacter pylori comb-nov and Helicobacter mustelae comb-nov, respectively. Int I Sys Bacteriol 1989, 39:397-405.

18. Forester NT, Parton K, Lumsden JS, O'Toole PW: Isolation of Helicobacter mustelae from ferrets in New Zealand. New Zealand Veterinary Journal 2000, 48:65-69.

19. Forester NT, Lumsden JS, Parton K, Cowan PE, O'Toole PW: Detection and isolation of Helicobacter mustelae from stoats in New Zealand. N Z Vet $J$ 2003, 51:142-145.

20. Fox JG, Otto G, Taylor NS, Rosenblad W, Murphy JC: Helicobacter mustelae -induced gastritis and elevated gastric $\mathrm{pH}$ in the ferret (Mustela putorius furo). Infect Immun 1991, 59:1875-1880.

21. Yu J, Russell RM, Salomon RN, Murphy JC, Palley LS, Fox JG: Effect of Helicobacter mustelae infection on ferret gastric epithelial cell proliferation. Carcinogenesis 1995, 16:1927-1931.

22. Fox JG, Dangler CA, Sager W, Borkowski R, Gliatto JM: Helicobacter mustelae-associated gastric adenocarcinoma in ferrets (Mustela putorius furo). Vet Pathol 1997, 34:225-229.

23. Erdman SE, Correa P, Coleman LA, Schrenzel MD, Li X, Fox JG: Helicobacter mustelae-associated gastric MALT lymphoma in ferrets. Am J Pathol 1997, 151:273-280.

24. Whary MT, Fox JG: Natural and experimental Helicobacter infections. Comp Med 2004, 54:128-158.

25. Gueneau P, Loiseaux-De Goer S: Helicobacter : molecular phylogeny and the origin of gastric colonization in the genus. Infect Genet Evol 2002, 1:215-223.

26. Dewhirst FE, Shen Z, Scimeca MS, Stokes LN, Boumenna T, Chen T, Paster BJ, Fox JG: Discordant 16S and 23S rRNA gene phylogenies for the genus Helicobacter: implications for phylogenetic inference and systematics. J Bacteriol 2005, 187:6106-6118.

27. Alm RA, Ling LS, Moir DT, King BL, Brown ED, Doig PC, Smith DR, Noonan B, Guild BC, deJonge BL, Carmel G, Tummino PJ, Caruso A, UriaNickelsen M, Mills DM, Ives C, Gibson R, Merberg D, Mills SD, Jiang Q, Taylor DE, Vovis GF, Trust TJ: Genomic sequence comparison of two unrelated isolates of the human gastric pathogen Helicobacter pylori. Nature 1999, 397:176-180.

28. Tomb JF, White O, Kerlavage AR, Clayton RA, Sutton GG, Fleischmann RD, Ketchum KA, Klenk HP, Gill S, Dougherty BA, et al: The complete genome sequence of the gastric pathogen Helicobacter pylori. Nature 1997, 388:539-547.

29. Suerbaum $S$, Josenhans $C$, Sterzenbach $T$, Drescher $B$, Brandt $P$, Bell $M$, Droge M, Fartmann B, Fischer HP, Ge Z, Horster A, Holland R, Klein K, Konig J, Macko L, Mendz GL, Nyakatura G, Schauer DB, Shen Z, Weber J, Frosch M, Fox JG: The complete genome sequence of the carcinogenic bacterium Helicobacter hepaticus. Proc Natl Acad Sci USA 2003, 100:7901-7906.

30. Eppinger M, Baar C, Linz B, Raddatz G, Lanz C, Keller H, Morelli G, Gressmann H, Achtman M, Schuster SC: Who ate whom? Adaptive Helicobacter genomic changes that accompanied a host jump from early humans to large felines. PLOS Genet 2006, 2:e120.

31. Parkhill J, Wren BW, Mungall K, Ketley JM, Churcher C, Basham D, Chillingworth T, Davies RM, Feltwell T, Holroyd S, Jagels K, Karlyshev AV, Moule S, Pallen MJ, Penn CW, Quail MA, Rajandream MA, Rutherford KM, van Vliet AH, Whitehead S, Barrell BG: The genome sequence of the foodborne pathogen Campylobacter jejuni reveals hypervariable sequences. Nature 2000, 403:665-668.

32. Pearson BM, Gaskin DJ, Segers RP, Wells JM, Nuijten PJ, van Vliet AH: The complete genome sequence of Campylobacter jejuni strain 81116 (NCTC11828). J Bacteriol 2007, 189:8402-8403.

33. Fouts DE, Mongodin EF, Mandrell RE, Miller WG, Rasko DA, Ravel J, Brinkac LM, DeBoy RT, Parker CT, Daugherty SC, Dodson RJ, Durkin AS, Madupu R, Sullivan SA, Shetty JU, Ayodeji MA, Shvartsbeyn A, Schatz MC, Badger JH, Fraser CM, Nelson KE: Major structural differences and novel potential virulence mechanisms from the genomes of multiple campylobacter species. PLoS Biol 2005, 3:e15.
34. Baar C, Eppinger M, Raddatz G, Simon J, Lanz C, Klimmek O, Nandakumar R, Gross R, Rosinus A, Keller H, Jagtap P, Linke B, Meyer F, Lederer $H$, Schuster SC: Complete genome sequence and analysis of Wolinella succinogenes. Proc Natl Acad Sci USA 2003, 100:11690-11695.

35. Eppinger M, Baar C, Raddatz G, Huson DH, Schuster SC: Comparative analysis of four Campylobacterales. Nat Rev Microbiol 2004, 2:872-885

36. Taylor DE, Chang N, Taylor NS, Fox JG: Genome conservation in Helicobacter mustelae as determined by pulsed-field gel electrophoresis. FEMS Microbiol Lett 1994, 118:31-36.

37. Megraud F, Neman-Simha V, Brugmann D: Further evidence of the toxic effect of ammonia produced by Helicobacter pylori urease on human epithelial cells. Infect Immun 1992, 60:1858-1863.

38. Andrutis KA, Fox JG, Schauer DB, Marini RP, Murphy JC, Yan L, Solnick JV: Inability of an isogenic urease-negative mutant stain of Helicobacter mustelae to colonize the ferret stomach. Infect Immun 1995, 63:3722-3725.

39. Solnick JV, Josenhans C, Suerbaum S, Tompkins LS, Labigne A: Construction and characterization of an isogenic urease-negative mutant of Helicobacter mustelae. Infect Immun 1995, 63:3718-3721.

40. Cuenca R, Blanchard TG, Czinn SJ, Nedrud JG, Monath TP, Lee CK, Redline RW: Therapeutic immunization against Helicobacter mustelae in naturally infected ferrets. Gastroenterology 1996, 110:1770-1775.

41. Stoof J, Breijer S, Pot RG, Neut van der D, Kuipers EJ, Kusters JG, van Vliet $\mathrm{AH}$ : Inverse nickel-responsive regulation of two urease enzymes in the gastric pathogen Helicobacter mustelae. Environ Microbiol 2008, 10:2586-2597.

42. OToole PW, Austin JW, Trust TJ: Identification and molecular characterization of a major ring-forming surface protein from the gastric pathogen Helicobacter mustelae. Mol Microbiol 1994, 11:349-361.

43. Patterson MM, O'Toole PW, Forester NT, Noonan B, Trust TJ, Xu S, Taylor NS, Marini RP, Ihrig MM, Fox JG: Failure of surface ring mutant strains of Helicobacter mustelae to persistently infect the ferret stomach. Infect Immun 2003, 71:2350-2355.

44. Forester NT, Lumsden JS, O'Croinín T, O'Toole PW: Sequence and antigenic variability of the Helicobacter mustelae surface ring protein Hsr. Infect Imun 2000, 69:3447-3450.

45. Josenhans C, Labigne A, Suerbaum S: Comparative ultrastructural and functional studies of Helicobacter pylori and Helicobacter mustelae flagellin mutants: both flagellin subunits, FlaA and FlaB, are necessary for full motility in Helicobacter species. J Bacteriol 1995, 177:3010-3020.

46. O'Toole PW, Kostrzynska M, Trust TJ: Non-motile mutants of Helicobacter pylori and Helicobacter mustelae defective in flagellar hook production. Mol Microbiol 1994, 14:691-703.

47. Monteiro MA, Zheng PY, Appelmelk BJ, Perry MB: The lipopolysaccharide of Helicobacter mustelae type strain ATCC 43772 expresses the monofucosyl A type 1 histo-blood group epitope. FEMS Microbiol Lett 1997, 154:103-109.

48. Croinin TO, Clyne M, Appelmelk BJ, Drumm B: Antigastric autoantibodies in ferrets naturally infected with Helicobacter mustelae. Infect Immun 2001, 69:2708-2713.

49. Therisod H, Monteiro MA, Perry MB, Caroff M: Helicobacter mustelae lipid A structure differs from that of Helicobacter pylori. FEBS Lett 2001, 499:1-5.

50. Croinin TO, McCormack A, van Vliet AH, Kusters JG, Bourke B: Random mutagenesis to identify novel Helicobacter mustelae virulence factors. FEMS Immunol Med Microbiol 2007, 50:257-263.

51. Josenhans C, Beier D, Linz B, Meyer TF, Suerbaum S: Pathogenomics of helicobacter. Int J Med Microbiol 2007, 297:589-600.

52. Dobrindt U, Hochhut B, Hentschel U, Hacker J: Genomic islands in pathogenic and environmental microorganisms. Nat Rev Microbiol 2004, 2:414-424.

53. Gal-Mor O, Finlay BB: Pathogenicity islands: a molecular toolbox for bacterial virulence. Cell Microbiol 2006, 8:1707-1719.

54. Covacci A, Falkow S, Berg DE, Rappuoli R: Did the inheritance of a pathogenicity island modify the virulence of Helicobacter pylori ? Trends Microbiol 1997, 5:205-208.

55. Bentley SD, Parkhill J: Comparative genomic structure of prokaryotes. Annu Rev Genet 2004, 38:771-792.

56. Parkhill J, Wren BW, Thomson NR, Titball RW, Holden MT, Prentice MB, Sebaihia M, James KD, Churcher C, Mungall KL, et al: Genome sequence of Yersinia pestis, the causative agent of plague. Nature 2001, 413:523-527. 
57. Suerbaum S, Smith JM, Bapumia K, Morelli G, Smith NH, Kunstmann E, Dyrek I, Achtman M: Free recombination within Helicobacter pylori. Proc Natl Acad Sci USA 1998, 95:12619-12624.

58. Barrangou R, Fremaux C, Deveau H, Richards M, Boyaval P, Moineau S, Romero DA, Horvath P: CRISPR provides acquired resistance against viruses in prokaryotes. Science 2007, 315:1709-1712.

59. Morgan DR, Fox JG, Leunk RD: Comparison of isolates of Helicobacter pylori and Helicobacter mustelae. J Clin Microbiol 1991, 29:395-397.

60. Nagata H, Wada A, Kurazono H, Yahiro K, Shirasaka D, Ikemura T, Aoyama N, Wang AP, Makiyama K, Kohno S, Hirayama T: Application of Bead-ELISA method to detect Helicobacter pylori VacA. Microb Pathog 1999, 26:103-110.

61. Alm RA, Bina J, Andrews BM, Doig P, Hancock RE, Trust TJ: Comparative genomics of Helicobacter pylori : analysis of the outer membrane protein families. Infect Imun 2000, 68:4155-4168.

62. Exner MM, Doig P, Trust TJ, Hancock RE: Isolation and characterization of a family of porin proteins from Helicobacter pylori. Infect Immun 1995, 63:1567-1572

63. Shen S, Mascarenhas M, Rahn K, Kaper JB, Karmali MA: Evidence for a hybrid genomic island in verocytotoxin-producing Escherichia coli CL3 (serotype 0113:H21) containing segments of EDL933 (serotype 0157:H7) $\mathrm{O}$ islands 122 and 48. Infect Immun 2004, 72:1496-1503.

64. Jonsson K, Guo BP, Monstein HJ, Mekalanos JJ, Kronvall G: Molecular cloning and characterization of two Helicobacter pylori genes coding for plasminogen-binding proteins. Proc Natl Acad Sci USA 2004, 101:1852-1857.

65. Konkel ME, Klena JD, Rivera-Amill V, Monteville MR, Biswas D, Raphael B, Mickelson J: Secretion of virulence proteins from Campylobacter jejuni is dependent on a functional flagellar export apparatus. J Bacterio/ 2004, 186:3296-3303.

66. Christensen JE, Pacheco SA, Konkel ME: Identification of a Campylobacter jejuni secreted protein required for maximal invasion of host cells. Mol Microbiol 2009, 73:650-662.

67. Nakagawa S, Takaki Y, Shimamura S, Reysenbach AL, Takai K, Horikoshi K: Deep-sea vent epsilon-proteobacterial genomes provide insights into emergence of pathogens. Proc Natl Acad Sci USA 2007, 104:12146-12150.

68. Szymanski CM, Burr DH, Guerry P: Campylobacter protein glycosylation affects host cell interactions. Infect Immun 2002, 70:2242-2244.

69. Szymanski CM, Wren BW: Protein glycosylation in bacterial mucosal pathogens. Nat Rev Microbiol 2005, 3:225-237.

70. Burucoa C, Fremaux C, Pei Z, Tummuru M, Blaser MJ, Cenatiempo Y, Fauchere $\mathrm{J}$ : Nucleotide sequence and characterization of peb4A encoding an antigenic protein in Campylobacter jejuni. Res Microbiol 1995, 146:467-476

71. Asakura H, Yamasaki M, Yamamoto S, Igimi S: Deletion of peb4 gene impairs cell adhesion and biofilm formation in Campylobacter jejuni. FEMS Microbiol Lett 2007, 275:278-285.

72. Evans DJ Jr, Evans DG, Takemura T, Nakano H, Lampert HC, Graham DY, Granger DN, Kvietys PR: Characterization of a Helicobacter pylori neutrophil-activating protein. Infect Immun 1995, 63:2213-2220.

73. Khoder G, Yamaoka Y, Fauchere JL, Burucoa C, Atanassov C: Proteomic Helicobacter pylori biomarkers discriminating between duodenal ulcer and gastric cancer. J Chromatogr B Analyt Technol Biomed Life Sci 2009, 877:1193-1199.

74. Cooksley C, Jenks PJ, Green A, Cockayne A, Logan RP, Hardie KR: NapA protects Helicobacter pylori from oxidative stress damage, and its production is influenced by the ferric uptake regulator. $J$ Med Microbiol 2003, 52:461-469.

75. Moran AP: Relevance of fucosylation and Lewis antigen expression in the bacterial gastroduodenal pathogen Helicobacter pylori. Carbohydr Res 2008, 343:1952-1965.

76. Appelmelk BJ, Monteiro MA, Martin SL, Moran AP, VandenbrouckeGrauls CM: Why Helicobacter pylori has Lewis antigens. Trends Microbiol 2000, 8:565-570.

77. Wang G, Ge Z, Rasko DA, Taylor DE: Lewis antigens in Helicobacter pylori : biosynthesis and phase variation. Mol Microbiol 2000, 36:1187-1196.

78. Croinin TO, Clyne M, Drumm B: Molecular mimicry of ferret gastric epithelial blood group antigen A by Helicobacter mustelae. Gastroenterology 1998, 114:690-696.
79. Andrutis KA, Fox JG, Schauer DB, Marini RP, Li X, Yan L, Josenhans C, Suerbaum S: Infection of the ferret stomach by isogenic flagellar mutant strains of Helicobacter mustelae. Infect Immun 1997, 65:1962-1966.

80. O'Toole PW, Lane MC, Porwollik S: Helicobacter pylori motility. Microbes \& Infection 2000, 2:1207-1214.

81. Schoenhofen IC, McNally DJ, Vinogradov E, Whitfield D, Young NM, Dick S, Wakarchuk WW, Brisson JR, Logan SM: Functional characterization of dehydratase/aminotransferase pairs from Helicobacter and Campylobacter: enzymes distinguishing the pseudaminic acid and bacillosamine biosynthetic pathways. J Biol Chem 2006, 281:723-732.

82. Schirm M, Soo EC, Aubry AJ, Austin J, Thibault P, Logan SM: Structural, genetic and functional characterization of the flagellin glycosylation process in Helicobacter pylori. Mol Microbiol 2003, 48:1579-1592.

83. Niehus E, Gressmann H, Ye F, Schlapbach R, Dehio M, Dehio C, Stack A, Meyer TF, Suerbaum S, Josenhans C: Genome-wide analysis of transcriptional hierarchy and feedback regulation in the flagellar system of Helicobacter pylori. Mol Microbiol 2004, 52:947-961.

84. Ryan KA, Karim N, Worku M, Penn CW, O'Toole PW: Helicobacter pylori flagellar hook-filament transition is controlled by a Flik functional homolog encoded by the gene HP0906. J Bacteriol 2005, 187:5742-5750.

85. Josenhans C, Eaton KA, Thevenot T, Suerbaum S: Switching of flagellar motility in Helicobacter pylori by reversible length variation of a short homopolymeric sequence repeat in fliP, a gene encoding a basal body protein. Infect Immun 2000, 68:4598-4603.

86. Voulhoux $\mathrm{R}$, Tommassen J: Omp85, an evolutionarily conserved bacterial protein involved in outer-membrane-protein assembly. Res Microbiol 2004, 155:129-135.

87. Jungblut PR, Bumann D, Haas G, Zimny-Arndt U, Holland P, Lamer S, Siejak F, Aebischer A, Meyer TF: Comparative proteome analysis of Helicobacter pylori. Mol Microbiol 2000, 36:710-725.

88. Catrenich CE, Makin KM: Characterization of the Morphologic Conversion of Helicobacter-Pylori from Bacillary to Coccoid Forms. Scand J Gastroenterol 1991, 26:58-64.

89. Cao P, McClain MS, Forsyth MH, Cover TL: Extracellular release of antigenic proteins by Helicobacter pylori. Infect Immun 1998, 66:2984-2986.

90. Frazier BA, Pfeifer JD, Russell DG, Falk P, Olsen AN, Hammar M, Westblom TU, Normark SJ: Paracrystalline inclusions of a novel ferritin containing nonheme iron, produced by the human gastric pathogen Helicobacter pylori: evidence for a third class of ferritins. J Bacterio/ 1993, 175:966-972

91. OToole PW, Logan SM, Kostrzynska M, Wadström T, Trust TJ: Isolation and biochemical and molecular analyses of a species-specific protein antigen from the gastric pathogen Helicobacter pylori. J Bacteriol 1991, 173:505-513.

92. Lundstrom AM, Sundaeus V, Bolin I: The 26-kilodalton, AhpC homologue, of Helicobacter pylori is also produced by other Helicobacter species. Helicobacter 2001, 6:44-54.

93. McGuire AM, Hughes JD, Church GM: Conservation of DNA regulatory motifs and discovery of new motifs in microbial genomes. Genome Res 2000, 10:744-757.

94. Eisen JA, Heidelberg JF, White O, Salzberg SL: Evidence for symmetric chromosomal inversions around the replication origin in bacteria. Genome Biol 2000, 1:RESEARCH0011.

95. Tillier ER, Collins RA: Genome rearrangement by replication-directed translocation. Nat Genet 2000, 26:195-197.

96. Canchaya C, Claesson MJ, Fitzgerald GF, van Sinderen D, O'Toole PW: Diversity of the genus Lactobacillus revealed by comparative genomics of five species. Microbiology 2006, 152:3185-3196.

97. Go MF: Natural history and epidemiology of Helicobacter pylori infection. Aliment Pharmacol Ther 2002, 16(Suppl 1):3-15.

98. Peek RM Jr, Crabtree JE: Helicobacter infection and gastric neoplasia. J Pathol 2006, 208:233-248.

99. Vogelmann R, Amieva MR: The role of bacterial pathogens in cancer. Curr Opin Microbiol 2007, 10:76-81.

100. Woude van der CJ, Kleibeuker JH, Jansen PL, Moshage H: Chronic inflammation, apoptosis and (pre-)malignant lesions in the gastrointestinal tract. Apoptosis 2004, 9:123-130.

101. Wen S, Moss SF: Helicobacter pylori virulence factors in gastric carcinogenesis. Cancer Lett 2009, 282:1-8. 
102. Romo-Gonzalez C, Salama NR, Burgeno-Ferreira J, Ponce-Castaneda V, Lazcano-Ponce E, Camorlinga-Ponce M, Torres J: Differences in genome content among Helicobacter pylori isolates from patients with gastritis, duodenal ulcer, or gastric cancer reveal novel disease-associated genes. Infect Immun 2009, 77:2201-2211.

103. Kikuchi S, Crabtree JE, Forman D, Kurosawa M: Association between infections with CagA-positive or -negative strains of Helicobacter pylori and risk for gastric cancer in young adults. Am J Gastroenterol 1999, 94:3455-3459.

104. Held M, Engstrand L, Hansson LE, Bergstrom R, Wadstrom T, Nyren O: Is the association between Helicobacter pylori and gastric cancer confined to CagA-positive strains? Helicobacter 2004, 9:271-277.

105. Kavermann H, Burns BP, Angermuller K, Odenbreit S, Fischer W, Melchers K, Haas R: Identification and characterization of Helicobacter pylori genes essential for gastric colonization. J Exp Med 2003, 197:813-822.

106. Whary MT, Andrews PLR: Physiology of the ferret. Biology and diseases of the ferret Baltimore MD USA: Lippincott Williams \& WilkinsFox JG 1998.

107. Wilson KT, Crabtree JE: Immunology of Helicobacter pylori : insights into the failure of the immune response and perspectives on vaccine studies. Gastroenterology 2007, 133:288-308.

108. Margolis $E$, Levin B: The evolution of bacteria-host interactions: virulence and the immune over-response. Introduction to the Evolutionary Biology of Bacterial and Fungal Pathogens Washington DC: ASM PressGutteriez J-A, Baquero FM 2008.

109. Ryan KA, Daly P, Li Y, Hooton C, O'Toole PW: Strain-specific inhibition of Helicobacter pylori by Lactobacillus salivarius and other lactobacilli. J Antimicrob Chemother 2008, 61:831-834.

110. Parkhill J, Achtman M, James KD, Bentley SD, Churcher C, Klee SR, Morelli G, Basham D, Brown D, Chillingworth T, Davies RM, Davis P, Devlin K, Feltwell T, Hamlin N, Holroyd S, Jagels K, Leather S, Moule S, Mungall K, Quail MA, Rajandream MA, Rutherford KM, Simmonds M, Skelton J, Whitehead S, Spratt BG, Barrell BG: Complete DNA sequence of a serogroup A strain of Neisseria meningitidis Z2491. Nature 2000, 404:502-506.

111. Bonfield JK, Rada C, Staden R: Automated detection of point mutations using fluorescent sequence trace subtraction. Nucleic Acids Res 1998, 26:3404-3409.

112. Rutherford K, Parkhill J, Crook J, Horsnell T, Rice P, Rajandream MA, Barrell B: Artemis: sequence visualization and annotation. Bioinformatics 2000, 16:944-945.

113. Frishman D, Mironov A, Mewes HW, Gelfand M: Combining diverse evidence for gene recognition in completely sequenced bacterial genomes. Nucleic Acids Res 1998, 26:2941-2947.

114. Delcher AL, Harmon D, Kasif S, White O, Salzberg SL: Improved microbial gene identification with GLIMMER. Nucleic Acids Res 1999, 27:4636-4641.

115. Larsen TS, Krogh A: EasyGene-a prokaryotic gene finder that ranks ORFs by statistical significance. BMC Bioinformatics 2003, 4:21.

116. Altschul SF, Gish W, Miller W, Myers EW, Lipman DJ: Basic local alignment search tool. J Mol Biol 1990, 215:403-410.

117. Pearson WR, Lipman DJ: Improved tools for biological sequence comparison. Proc Natl Acad Sci USA 1988, 85:2444-2448.

118. Bateman A, Coin L, Durbin R, Finn RD, Hollich V, Griffiths-Jones S, Khanna A, Marshall M, Moxon S, Sonnhammer EL, Studholme DJ, Yeats C, Eddy SR: The Pfam protein families database. Nucleic Acids Res 2004, 32:D138-141.

119. Falquet L, Pagni M, Bucher P, Hulo N, Sigrist CJ, Hofmann K, Bairoch A: The PROSITE database, its status in 2002. Nucleic Acids Res 2002, 30:235-238.

120. Krogh A, Larsson B, von Heijne G, Sonnhammer EL: Predicting transmembrane protein topology with a hidden Markov model: application to complete genomes. J Mol Biol 2001, 305:567-580.

121. Nielsen $H$, Krogh A: Prediction of signal peptides and signal anchors by a hidden Markov model. Proc Int Conf Intell Syst Mol Biol 1998, 6:122-130.

122. Lowe TM, Eddy SR: tRNAscan-SE: a program for improved detection of transfer RNA genes in genomic sequence. Nucleic Acids Res 1997, 25:955-964.

123. Griffiths-Jones S, Bateman A, Marshall M, Khanna A, Eddy SR: Rfam: an RNA family database. Nucleic Acids Res 2003, 31:439-441.

124. Ghai R, Chakraborty T: Comparative microbial genome visualization using GenomeViz. Methods Mol Biol 2007, 395:97-108.

125. Vernikos GS, Parkhill J: Interpolated variable order motifs for identification of horizontally acquired DNA: revisiting the Salmonella pathogenicity islands. Bioinformatics 2006, 22:2196-2203.
126. Bailey TL, Boden M, Buske FA, Frith M, Grant CE, Clementi L, Ren J, Li WW, Noble WS: MEME SUITE: tools for motif discovery and searching. Nucleic Acids Res 2009, 37:W202-208.

127. Edgar RC: MUSCLE: multiple sequence alignment with high accuracy and high throughput. Nucleic Acids Res 2004, 32:1792-1797.

128. Dereeper A, Guignon V, Blanc G, Audic S, Buffet S, Chevenet F, Dufayard JF, Guindon S, Lefort V, Lescot M, Claverie JM, Gascuel O: Phylogeny.fr: robust phylogenetic analysis for the non-specialist. Nucleic Acids Res 2008, 36 W465-469.

129. Guindon S, Gascuel O: A simple, fast, and accurate algorithm to estimate large phylogenies by maximum likelihood. Syst Biol 2003, 52:696-704.

130. Anisimova M, Gascuel O: Approximate likelihood-ratio test for branches: A fast, accurate, and powerful alternative. Syst Biol 2006, 55:539-552.

131. Carver TJ, Rutherford KM, Berriman M, Rajandream MA, Barrell BG, Parkhill J: ACT: the Artemis Comparison Tool. Bioinformatics 2005, 21:3422-3423.

132. Keane TM, Naughton TJ, Mclnerney JO: MultiPhyl: a high-throughput phylogenomics webserver using distributed computing. Nucleic Acids Res 2007, 35:W33-37.

133. Katoh K, Misawa K, Kuma K, Miyata T: MAFFT: a novel method for rapid multiple sequence alignment based on fast Fourier transform. Nucleic Acids Res 2002, 30:3059-3066.

134. Talavera G, Castresana J: Improvement of phylogenies after removing divergent and ambiguously aligned blocks from protein sequence alignments. Syst Biol 2007, 56:564-577.

135. Page RD: Visualizing phylogenetic trees using TreeView. Curr Protoc Bioinformatics 2002, Chapter 6, Unit $62 .$.

136. Graham RL, O'Loughlin SN, Pollock CE, Ternan NG, Weatherly DB, Jackson PJ, Tarleton RL, McMullan G: A combined shotgun and multidimensional proteomic analysis of the insoluble subproteome of the obligate thermophile, Geobacillus thermoleovorans T80. J Proteome Res 2006, 5:2465-2473.

137. Bradford MM: A rapid and sensitive method for the quantitation of microgram quantities of protein utilizing the principle of protein-dye binding. Anal Biochem 1976, 72:248-254.

138. Graham RL, Pollock CE, Ternan NG, McMullan G: Top-down proteomic analysis of the soluble sub-proteome of the obligate thermophile, Geobacillus thermoleovorans T80: insights into its cellular processes. J Proteome Res 2006, 5:822-828.

139. Graham RL, Sharma MK, Ternan NG, Weatherly DB, Tarleton RL, McMullan G: A semi-quantitative GeLC-MS analysis of temporal proteome expression in the emerging nosocomial pathogen Ochrobactrum anthropi. Genome Biol 2007, 8:R110.

140. Weatherly DB, Atwood JA, Minning TA, Cavola C, Tarleton RL, Orlando R: A Heuristic method for assigning a false-discovery rate for protein identifications from Mascot database search results. Mol Cell Proteomics 2005, 4:762-772.

141. Ishihama Y, Oda Y, Tabata T, Sato T, Nagasu T, Rappsilber J, Mann M: Exponentially modified protein abundance index (emPAl) for estimation of absolute protein amount in proteomics by the number of sequenced peptides per protein. Mol Cell Proteomics 2005, 4:1265-1272.

142. Pilch B, Mann M: Large-scale and high-confidence proteomic analysis of human seminal plasma. Genome Biol 2006, 7:R40.

143. Boneca IG, de Reuse H, Epinat JC, Pupin M, Labigne A, Moszer I: A revised annotation and comparative analysis of Helicobacter pylori genomes. Nucleic Acids Res 2003, 31:1704-1714.

doi:10.1186/1471-2164-11-164

Cite this article as: OToole et al:: Comparative genomics and proteomics of Helicobacter mustelae, an ulcerogenic and carcinogenic gastric pathogen. BMC Genomics 2010 11:164. 